\title{
Effect of Direction of Training Los in accordance with the limitations of biorhythm on the level of special motor skills and skill performance of motor package (kata) in the players of the Egyptian National Karate Team \\ Lecturer Dr. Reda Youssef Yousry Abdelker
}

\section{Introduction and Problem of the Research.}

Scientific research is important for making cultural progress and human development in the different fields of life in the modern era. It has become common to note the positive and clear relationship between the countries that me significant scientific and technical progress, and its sports superiority in the international championships and Olympic games.

Biorhythm is one of the modern science used in the field of physical education. The efficiency of work for individuals varies if works are performed in different times of the day and in the field of sports. As a result, we h to guide the importance of biorhythm in the field of sports. The high sports results in terms of numbers and skill performance levels during the international championships and Olympic tournaments show the need to use scientific research to reach new sources that can help upgrade the efficiency of sports training and to devise new trends related to the nature of specialized sports activity.
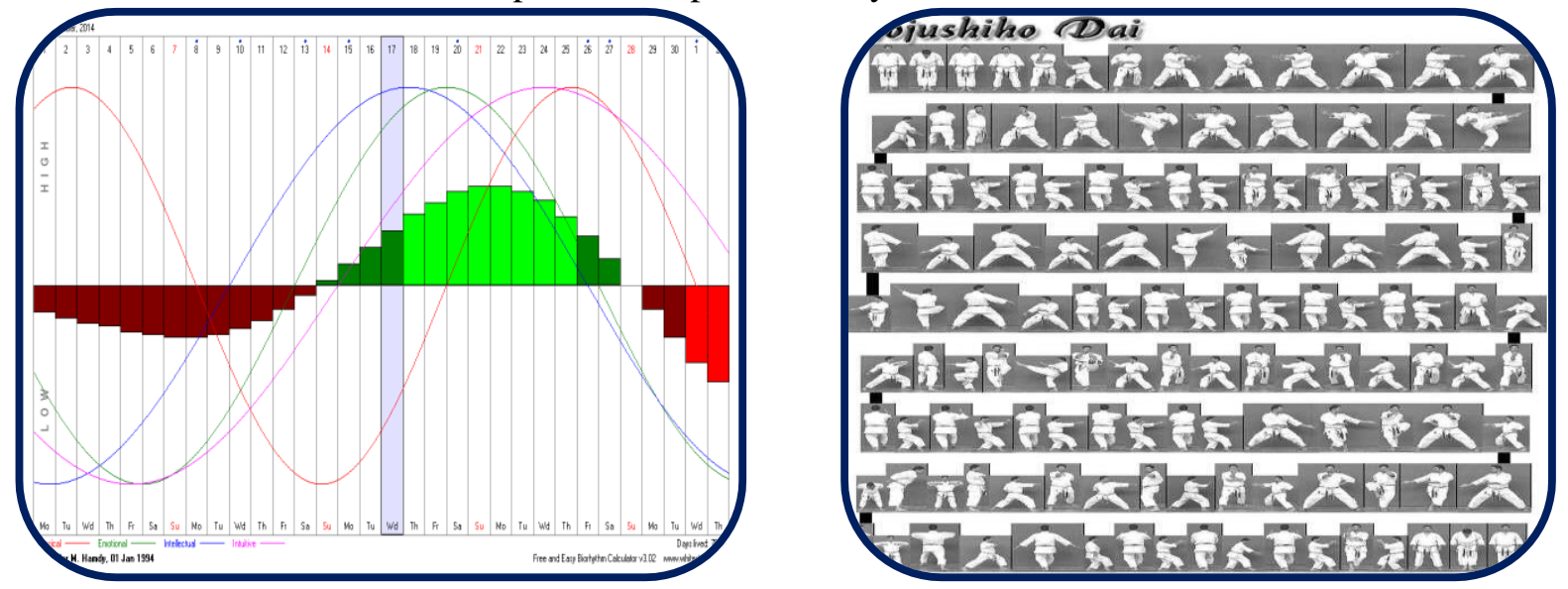

Figure (1)

Track of dynamics of the value of monthly biorhythm limitations to the player of the study in September 2014 (Goju Shi Ho Dai. Kata)

Ahmed Mahmoud Ibrahim and Amrallah Ahmed (1999), Gupta A. et Al (2009), Gokul S. et al (2010), note the importance of biorhythm and its effect on the physical limitations and their relation to efficiency of biosystems in the human body and its ability to work over the day, and importance of it for the sports activity in general and within the creation

* Lecturer at the Department of Duels and Water Sports, Faculty of Physical Education, Sat University 
of new training approaches. Scientific research and studies try to determine the key functional and physical-skill requirements required by the nature and characteristics of the sports activity exercised, and positively affect the effect of training to reach high sports levels (5). (19), (20).

Ali Fahym Al Bek (1990); Youssef Dahab Ali (2002) and Cutolo M. (2012) note that biorhythms include more than 400 body functions. Biorhythm of body temperature in the lowest degrees of reduction in the morning, then body temperature rises as biorhythm of the body is considered in the lowest degrees of decrease in the morning then body temperature rises to reach the maximum at six in the evening. The general body rhythm in 24 hours is more active during specific period of the day. In the morning, from 9 am to $1 \mathrm{pm}$, and the evening period from 4 in the afternoon to 8 in the evening. (11), (16), (17)

In dition, Ali Al Bek and Sabry Omar (1994), Fory M. Miskin. R. (2010) notes that daily biorhythm of the functional activity of the nervous system and the individual work system play key role in time alignment of all operations that occur as frequent courses and daily fluctuations of the nervous system activity in man is closely related to the cycle of sleeping and waking up. (12), (18)

Essam EL Din Abdelkhalek (2003) notes that skill performance is closely related to the special physical and motor abilities over the development of this performance in special physical and motor abilities such as speed force, force endurance, accuracy, speed, alignment and agility. This skill performance is often measured on the individual's acquisition of these special physical and motor skills. (10)

Ahmed Mahmoud Ibrahim (2005) notes that karate with the skill styles whether defensive or attack that it contains, requires special physical requirements that contribute to development of skill performance and sports achievement, because physical abilities are related to the nature of skill performance in the specialized sports activity of the player. In dition, the distinctive nature of basic motor skills for the type of specialized activity defines the quality of necessary physical abilities that shall follow their development dynamics through physical skill tests of their own, during the periods of development of the structure such as the player's training status in general and the physical structure in particular. Since karate player needs many skill physical capacities of the performance of defense or attack through the competitions of actual fighting "Kumite" and false fighting "Kata". There are tests for evaluation of physicalskill abilities for revenge and evaluation of the phases of development of performance skills on the one hand, and the similar performance style to the skill style of player on the other. That is, there is test that evaluates the speed force as special physical capacity of karate player with use of actual performance of Gayku. Zuki and maintenance of performance properties from the motor track, speed rhythm and performance force through performance. This achieves modeling between the quantitative evaluation of special physical capacity and descriptive evaluation of the performed skill style. (3).

Requirements of sports achievement of karate player, specialization of false combat competition "Kata" by multiplicity of its schools and components of each of its elements is important for trainer, player and planner of training los. In dition, multiplicity of styles between 
Shorai Style, Shoren Style and Kata is multiple and requires the player or team to perform it through the different playing roles in the championship "preparatory session, final session, satisfaction session". This requires certain level that shall be possessed of the skill styles and physical-skill limitations of performance to continue in competition for long period during the same day. In dition, it requires rated planning in accordance with the type of championship and requirements of performance of the motor package "Kata" performed during the competition using the right rated method of training that matches the nature of kata. This indicates the importance of scientific planning of player or team that participates in the championship to reach the highest levels of sports achievement. (22)

From the foregoing, the researcher believes that importance of biorhythm appears in itst role that affects the values of physical limitations and their relation to the efficiency of bio systems in the human body and their ability to work round the day, and the importance of this for the sports activity. Within the creation of new approaches of training, scientific researches and studies try to determine the key physical-skill requirements required for the nature and characteristics of the sports activity practiced. In edition, it can positively affect the process of training to reach the high sports levels. The researcher noted through his experience as former international player and trainer of the Tunisian and Egyptian teams that their skill style performance that comprises the structure of kata is low through the performance of some players in the local and international competitions. According to the researcher, this decrease may be attributed to deficit of motor capacities of these skill styles. Kata that player or team shall perform during the different playing roles of the championship "preparatory, pre final, final and satisfaction roles" require specific standard that shall be possessed in the skill styles and physical- skill limitations of performance to continue the game for long period of time during the same day. Majority of trainers don't pay attention to scientific planning of special motor skills. This is the basis on which the components of structure of Kata are founded, taking into account that the level of special motor skills affects the skill performance and therefore affects the match result, so the researcher considered this study to develop the special motor skills of to make benefit of them in the development of Kata performance of karate players.

The idea of the study is crystallized in creation of a new means for increasing the effectiveness of training programs by using biorhythm curves through the components of structure of the training program the importance of which lies in contribute to promote the players' performance in terms of skills and effect on the development of the motor skills of kata players.

\section{Terms of the study:}

\section{Biorhythm}

These regular biological effects of close or far progress through which the physical, mental and emotional activity of man increases or decreases. These changes are related to the internal and external environment. (11)

\section{Goju Shi Ho Dai. Kata}


This is an international motor package, one of the advanced motor packages in the Shotokan schools. It means (54) big steps. It is distinguished with fast movement of arms in all direction and multiplicity of stops, particularly the cat stop and the horse stop. It requires high degree of stability to save it. Its movements are (62) and the percentage of defensive styles (45.59\%); attack (59.94\%) and requires approximately (90) seconds. (21)

\section{Special motor skills:}

Package of physical characteristics of the player related to the skill performance and help the player to perform and be distinguished during the performance of motor package. (Procedural)

\section{Aim of the study:}

Identification of the effect of using biorhythm track limitations to direct the training los of motor skills on the level of motor package "kata" performance of the Egyptian karate players.

\section{Hypotheses of the study:}

1- There is positive improvement in the values of special motor skills- skill styles- training packages- time and level of performance of motor package (Goju. Shi. Ho. Dai. Kata) under study in the Egyptian national team player who doesn't use the biorhythm curves in direction of training los under study.

2- There is positive improvement in the percentage values of special motor capacities, skill styles, training packages, time and standard of kata performance under study in the sample of the study using biorhythm curves during the direction of training los under study.

3- There are differences in the percentages of positive percentage improvement in the values of special motor skills, skill styles, training packages, time and level of performance of motor skills "Kata" under study in sample of the study for the favor of those that use against those that don't use the biorhythm curves during the direction of training los under study.

\section{Procedures of the study}

\section{Methodology}

The experimental methodology was used by designing the pre and post measurements of one experimental group because it is suitable to the nature of the study.

\section{Sample}

The sample of the study was chosen in the purposeful method of the Egyptian national team players, specialization of kata, that participated in World Karate Championship in Germany 2014, and the total number was (1) individual kata player as main sample, and pilot sample of (20) players to conduct the scientific treatments under study.

\section{Measurements and tests used in the study:}

First: Tests of special motor capacities under study:

- Speed force for the skill styles that are mostly used or those that form the structure of Goju Shi Ho Dai. Kata 
- Speed endurance for the most mused skill styles that form the structure of motor package under study.

- Force endurance for the most used skill styles that form the structure of motor package under study.

- Agility of the most used motor styles that form the structure of motor package under study.

Third: Measurement of performance standard and skill styles that comprise the structure of motor package Goju Shi Ho Dai. Kata, including:

- Straight reverse punch Gayku.Zuki

- Long straight punch Oi.Zuki

- One-finger spear-hand Ippon Nukite

- Front kick Mae. Geri

Second: Measurement of the performance of training parts of motor package Kata Goju Shi Ho Dai

Third: measurement of the time and level of performance of motor package Goju. Kata

\section{Shi Ho Dai}

The skill tests were conducted in accordance with the international standards of kata arbitration law.

Fifth: Tests of evaluation and drawing of biorhythm using (easy biorhythm calculator)

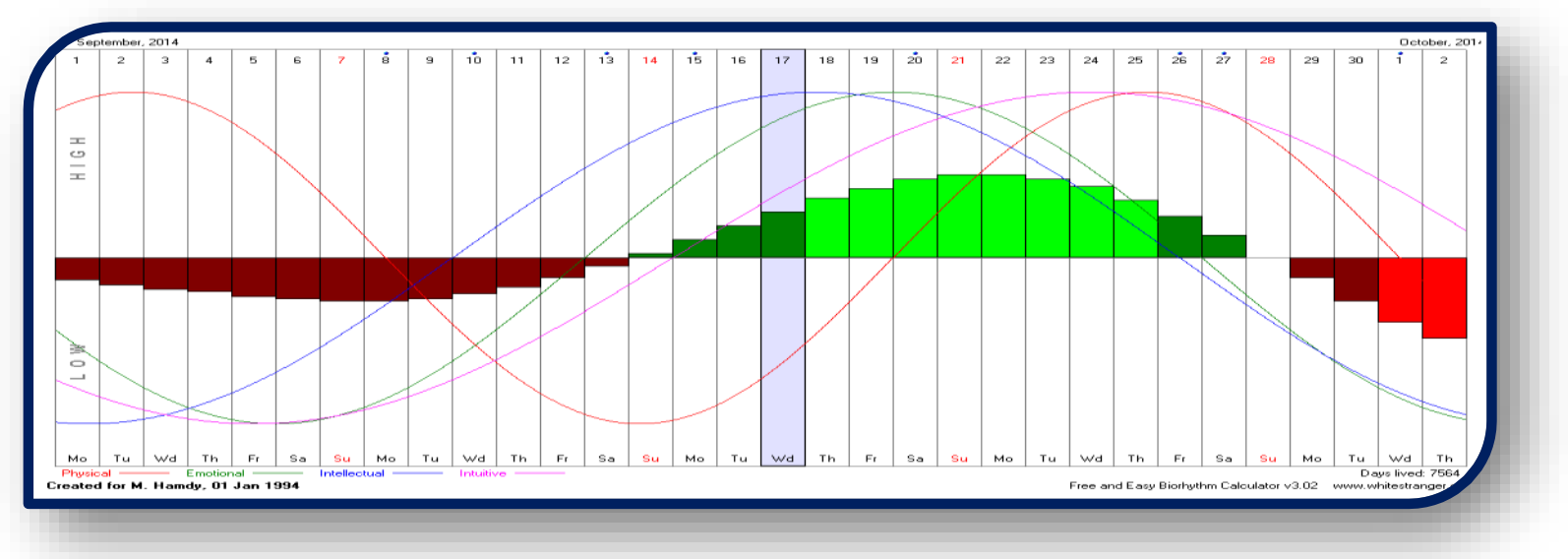

Figure (2)

Track of dynamics of the value of monthly biorhythm limitations of the player the of the study in September 2014

Form under study:

- Skill performance standard evaluation form. Attachment (8)

- Forms (collection of data, survey of experts, transcription of data) attachment (1) and (2) 
Pilot studies to conduct the practical transactions of special motor skill tests under study:

Pilot studies were conducted on sample of (20) players out of the basic sample of the study of the Cairo Karate Zone, specialization of kata, to conduct the survey studies of motor skill tests and the skill tests under study on Wednesday and Thursday, 9 and 10/07/2014 as first application, and Thursday and Friday, 17, 18/07/2014 as second application with difference of one week, seven (7) days between the two applications.

Table (1) scientific treatments of the special motor capacity tests under study

\begin{tabular}{|c|c|c|c|c|c|}
\hline \multicolumn{2}{|c|}{ Tests under study } & Performed side & Unit of Meas. & Reliability & Stability \\
\hline \multirow{8}{*}{ 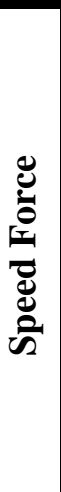 } & \multirow{2}{*}{ (Gayku.Zuki) } & Right & No. & 0.95 & 0.96 \\
\hline & & Left & No. & 0.97 & 0.97 \\
\hline & \multirow{2}{*}{ (Oi.Zuki) } & Right & No. & 0.92 & 0.93 \\
\hline & & Left & No. & 0.94 & 0.95 \\
\hline & \multirow{2}{*}{ (Ippon.Nukite) } & Right & No. & 0.89 & 0.86 \\
\hline & & Left & No. & 0.92 & 0.90 \\
\hline & \multirow{2}{*}{ (Mae.Geri) } & Right & No. & 0.97 & 0.96 \\
\hline & & Left & No. & 0.99 & 0.97 \\
\hline \multirow{8}{*}{ 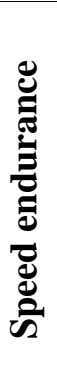 } & \multirow{2}{*}{ (Gayku.Zuki) } & Right & No. & 0.96 & 0.94 \\
\hline & & Left & No. & 0.98 & 0.97 \\
\hline & \multirow{2}{*}{ (Oi.Zuki) } & Right & No. & 0.94 & 0.90 \\
\hline & & Left & No. & 0.96 & 0.94 \\
\hline & \multirow{2}{*}{ (Ippon.Nukite) } & Right & No. & 0.93 & 0.90 \\
\hline & & Left & No. & 0.95 & 0.93 \\
\hline & \multirow{2}{*}{ (Mae.Geri } & Right & No. & 0.96 & 0.94 \\
\hline & & Left & No. & 0.97 & 0.96 \\
\hline \multirow{8}{*}{ 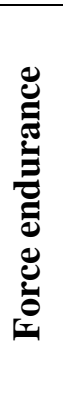 } & \multirow{2}{*}{ (Gayku.Zuki) } & Right & No. & 0.94 & 0.90 \\
\hline & & Left & No. & 0.96 & 0.93 \\
\hline & \multirow{2}{*}{ (Oi.Zuki) } & Right & No. & 0.96 & 0.92 \\
\hline & & Left & No. & 0.97 & 0.94 \\
\hline & \multirow{2}{*}{ (Ippon.Nukite) } & Right & No. & 0.95 & 0.90 \\
\hline & & Left & No. & 0.97 & 0.95 \\
\hline & \multirow{2}{*}{ (Mae.Geri) } & Right & No. & 0.95 & 0.90 \\
\hline & & Left & No. & 0.97 & 0.96 \\
\hline \multirow{8}{*}{ 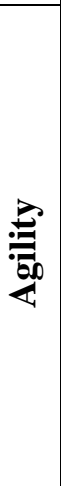 } & \multirow{2}{*}{ (Gayku.Zuki) } & Right & Second & 0.95 & 0.92 \\
\hline & & Left & Second & 0.96 & 0.95 \\
\hline & \multirow{2}{*}{ (Oi.Zuki) } & Right & Second & 0.96 & 0.92 \\
\hline & & Left & Second & 0.97 & 0.94 \\
\hline & \multirow{2}{*}{ (Ippon.Nukite) } & Right & Second & 0.90 & 0.89 \\
\hline & & Left & Second & 0.93 & 0.90 \\
\hline & \multirow{2}{*}{ (Mae.Geri) } & Right & Second & 0.92 & 0.88 \\
\hline & & Left & Second & 0.94 & 0.91 \\
\hline
\end{tabular}




\section{Proposed training program:}

The training program was applied to the main sample of the study for (8) weeks with average of (4 weeks without use of biorhythm curves, 4- weeks with use of biorhythm curves) training days per week in the period from Friday, 01/08/2014 to Sunday, 28/09/2014 in the sports hall

in Tolip Hotel, in accordance with the following table:

Table (2) Time distribution of the main experiment of the study

\begin{tabular}{|c|c|c|}
\hline Measurements & Day-Date & Measures \\
\hline \multirow{3}{*}{$\begin{array}{c}\text { Pre } \\
\text { measurements }\end{array}$} & - First day, Monday, 28/07/2014 & $\begin{array}{l}\text { - Evaluation of skill performance standard of the skill } \\
\text { styles individually. } \\
\text { - Evaluation of the skill performance standard of training } \\
\text { sections in the motor package. Kata GojuShi Ho Dai } \\
\text { - Evaluation of the time and standard of skill } \\
\text { performance of the motor section Goju Shi Ho Dai. Kata }\end{array}$ \\
\hline & - Second Day: Thursday, 29/07/2014 & $\begin{array}{l}\text { Evaluation of special motor skills by skill style of (Oi. } \\
\text { Zuki) } \\
\text { Evaluation of motor skills of the skill style of (Ippon. } \\
\text { Nukite) }\end{array}$ \\
\hline & - Third Day: Wednesday, 30/07/2014 & $\begin{array}{l}\text { - Evaluation of motor skills of (Gayku. Zuki) } \\
\text { - Evaluation of motor capacities of (Mae. Geri) }\end{array}$ \\
\hline $\begin{array}{c}\text { Main } \\
\text { Experiment }\end{array}$ & $\begin{array}{l}4 \text { weeks without use of biorhythm curves, } \\
\text { from1- 27/08/2014 ( } 4 \text { weeks with use of } \\
\text { biorhythm curves) from, 2- 28/09/2014 } \\
\text { Post meas., were me for the "without" } \\
\text { period and pre meas., for the "with" period } \\
\text { using days of 29, 30, 31/08/2014 }\end{array}$ & $\begin{array}{l}\text { - Main Experiment for Application of the training } \\
\text { program that consists of } 40 \text { proposed training modules } \\
\text { with average of } 5 \text { units per week. }\end{array}$ \\
\hline \multirow{3}{*}{$\begin{array}{l}\text { Post } \\
\text { measurements }\end{array}$} & First Day: Tuesday, 30/09/2014 & $\begin{array}{l}\text { - Evaluation of the skill performance of skill styles } \\
\text { "Individually" } \\
\text { - Evaluation of the skill performance standard of training } \\
\text { sections in the motor package GojuShi Ho Dai Kata } \\
\text { - Evaluation of the time and standard of skill } \\
\text { performance of the motor section Goju Shi Ho Dai. Kata }\end{array}$ \\
\hline & - Second Day: Tuesday, 01/10/2014 & $\begin{array}{l}\text { Evaluation of special motor skills by skill style of (Oi. } \\
\text { Zuki) } \\
\text { Evaluation of motor skills of the skill style of (Ippon. } \\
\text { Nukite) }\end{array}$ \\
\hline & Third Day: Wednesday, 02/10/2014 & $\begin{array}{l}\text { - Evaluation of motor skills of (Gayku. Zuki) } \\
\text { - Evaluation of motor capacities of (Mae. Geri) }\end{array}$ \\
\hline
\end{tabular}


Content and properties of the proposed training program :

By using literatures (1), (2), (3), (4), (10), (13) and (16), the content and properties of the proposed training program were determined as follows:

Table (3)

Properties of the proposed and implementing training program under study

\begin{tabular}{|c|c|}
\hline Properties & Time distribution of the program \\
\hline General period for application of the study & Special preparation, before competition \\
\hline Number of application weeks & $\begin{array}{l}8 \text { training weeks ( } 4 \text { weeks without rhythm- } 4 \text { weeks using } \\
\text { rhythm) }\end{array}$ \\
\hline Number of training modules & 40 training modules \\
\hline Number of times of weekly training & $\begin{array}{l}5 \text { Times of training per week (Friday, Saturday, Sunday, } \\
\text { Wednesday) }\end{array}$ \\
\hline Time of application of unit & Ranges between ( 2138 second) and ( 3550 second) \\
\hline Overall time of the program & (30163) second or (1002.72) minutes approximately \\
\hline $\begin{array}{c}\text { Percentage of interval rest period between } \\
\text { training stations }\end{array}$ & $(1: 1,0.5: 1)$ was (work: rest) \\
\hline Period of rest between training packages & $(1: 1,0.5: 1)$ was (work: rest) \\
\hline Degrees of training los & $\begin{array}{l}\text { Average }(50: 75) \text {, less than maximum }(70: 75) \text {, maximum } \\
(90: 100)\end{array}$ \\
\hline Applied training method & In high and low intensity periodic training method \\
\hline
\end{tabular}

Table (4)

Time distribution of the training program on parts of the training unit

\begin{tabular}{|c|c|c|c|c|}
\hline No & \multicolumn{2}{|c|}{ Parts of training modules } & Percentage (\%) & Time (second) \\
\hline \multirow[t]{2}{*}{1} & \multirow{2}{*}{$\begin{array}{c}\text { Preparatory } \\
\text { part }\end{array}$} & Warm up (preparation) & 29.92 & 18000 \\
\hline & & $\begin{array}{c}\text { Special physical } \\
\text { preparation }\end{array}$ & 9.36 & 5630 \\
\hline \multirow{3}{*}{2} & \multirow{3}{*}{ Main Part } & Competition exercises (1) & 20.84 & 12535 \\
\hline & & Competition exercises (2) & 7.36 & 4428 \\
\hline & & (Match Training) & 22.56 & 13570 \\
\hline 3 & Final part & Warm Down & 9.97 & 6000 \\
\hline \multicolumn{3}{|c|}{ Total } & 100 & 60163 \\
\hline
\end{tabular}




\section{Proposed training loads through the units of the proposed training program:}

The proposed training program was applied using the periodic training style. The daily training unit consisted of three parties (preparatory, main, final)

\section{First: Preparatory Part: Warm up:}

Warm up includes the exercises of light running, exercises of muscle warm up and general activation of blood circulation, stretch exercises and some exercises that contribute to raise the body temperature so that the organs of the body and nervous and physiological parts of the body become ready to admit the content of training unit, and the exercises of flexibility of the body as a whole and focus on them to restore rapid recovery from the technical exercise effect that immediately precede the physical skills, and prepare them for performance of the content of the main part, raise their capacities and direct the content of this stage to the aerobic work so that training loan ranges between $(40: 45 \%)$ of the maximum capacity of player. The total time of this section was (1800 seconds); that is, with percentage of $(29.92 \%)$ of the overall time of the proposed program under study.

\section{Special physical preparation}

This includes three training stations with training load intensity between $(62: 70 \%)$ of the maximum frequency of right performance per exercise. During the execution of performance, use of over average and normal speed were used. Exercises were directed to serve the working muscles and participation through the performance of punches, kicks, balance positions, change of most used directions in the motor package .Kata Goju Shi Ho Dai, but they are not similar with performance itself in terms of the motor track and time rhythm. Scientific basis of formation of rated and wavy training los were considered in enforcement. In dition, these los were directed in accordance with the mixed functional work (aerobic + anaerobic). The total time of this section was (6305 seconds); that is, with percentage of $(9.36 \%)$ of the total time of the proposed program under study. Figure (3)

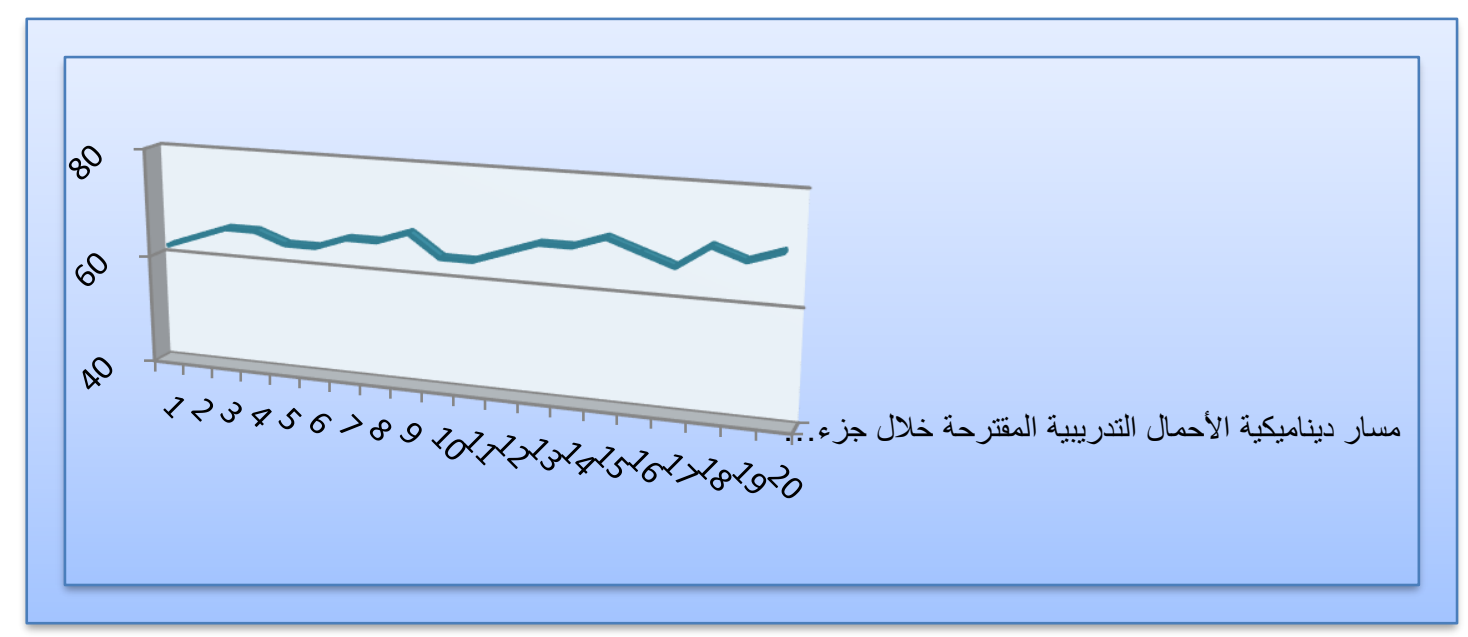

Figure (3)

Track of dynamics of training loads proposed during the part 


\section{Second: Main Part:}

\section{of special physical preparation}

This part includes three different sections (competition exercises using the skill styles performed individually, competition exercises using the nine training sections that compose the structure of Kata package under study, game training in motor performance of motor package "Kata" as a whole in accordance with qualifiers). Each of them has objective and contents. The total time of this section was (30533 seconds); that is, with percentage of $(50.75 \%)$ of the total time of the proposed training program under study.

\section{Section one: competition exercises using the individually performed skill styles:}

This section includes 12 training stations with intensity between $(70: 80 \%)$ of the maximum repetition of right performance of each exercise with stability of the performance time during the training station (second). The training stations were distributed into 8 training stations for the right and left individual performance and 4 training stations for the consecutive individual performance. During the execution of performance, use of over average and high speed was used to maintaining the motor track of performance. The training stations including the individual skill styles that comprise the structure of motor package under study, and the most repeated one, which is the straight reverse punch (Gayku-Zuki), straight long punch (Oi. Zuki), one-finger spear-hand (Ippon. Nukite), front kick (Mae. Geri). Scientific bases of formation of rated and wavy training los were taken into account during the enforcement. In dition, these los were directed in accordance with the mixed functional work (aerobicanaerobic). The total time of this section was (12535 seconds); that is, with percentage of (20.84\%) of the total time of the proposed program under study. Figure (4)

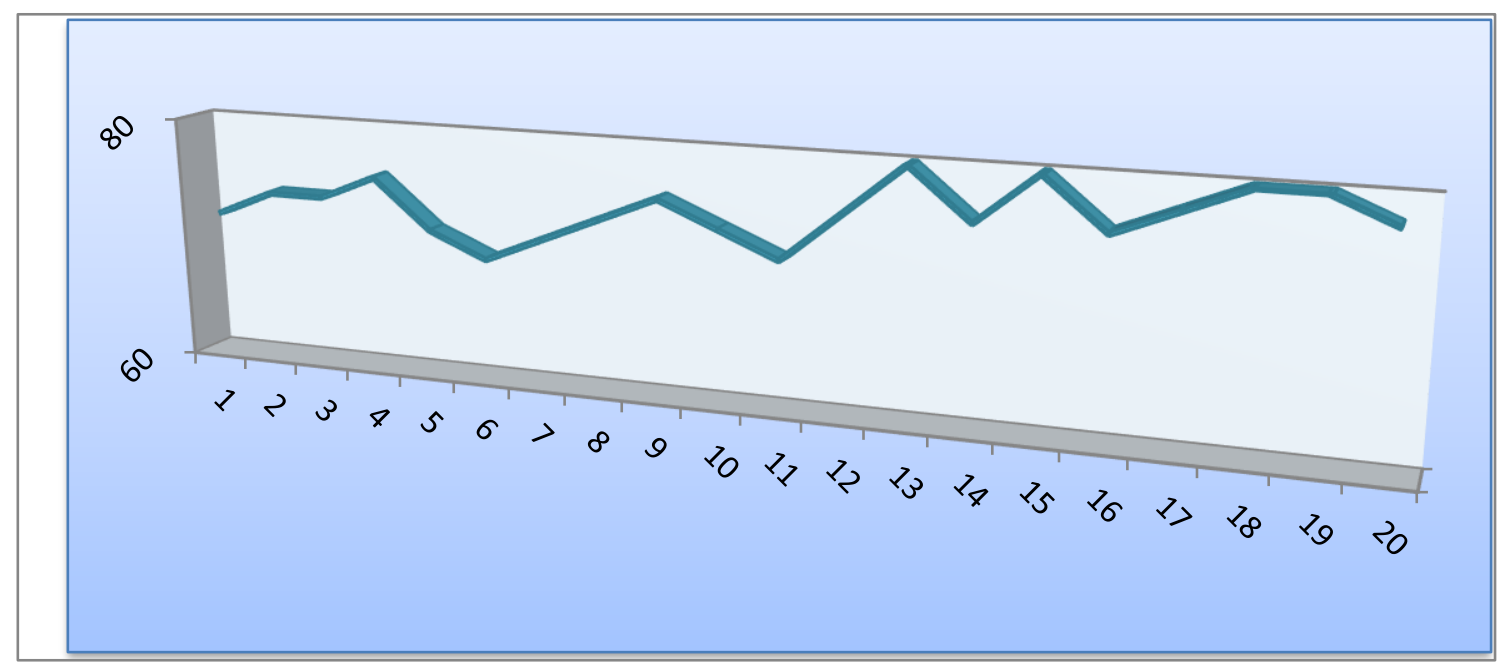

Figure (4)

Track of proposed training loads dynamics during the part of competition (1) 
Section two: competition exercises using training sections that comprise the structure of "Kata" package under study:

This section includes the competition exercises using the training sections that comprise the structure of motor package .Kata Goju Shi Ho Dai, which consist of 4 rated training packages. The first training package includes the skill styles (1-14), the second training package of the skill styles (15-31), third training package of the skill styles (32-45); fourth training section of skill styles (46-68), and the intensity of training lo ranges between $(78: 84 \%)$ of the maximum performance during specific time for individual rating. This section was executed in time of (4428 seconds) with percentage of $(7.36 \%)$ of the overall time of training program, with performance of the motor duties with performance speed similar to the nature of performance of international motor package under study. The anaerobic functional trend was maintained in performance during the execution of the content of this section of training unit. Figure (5)

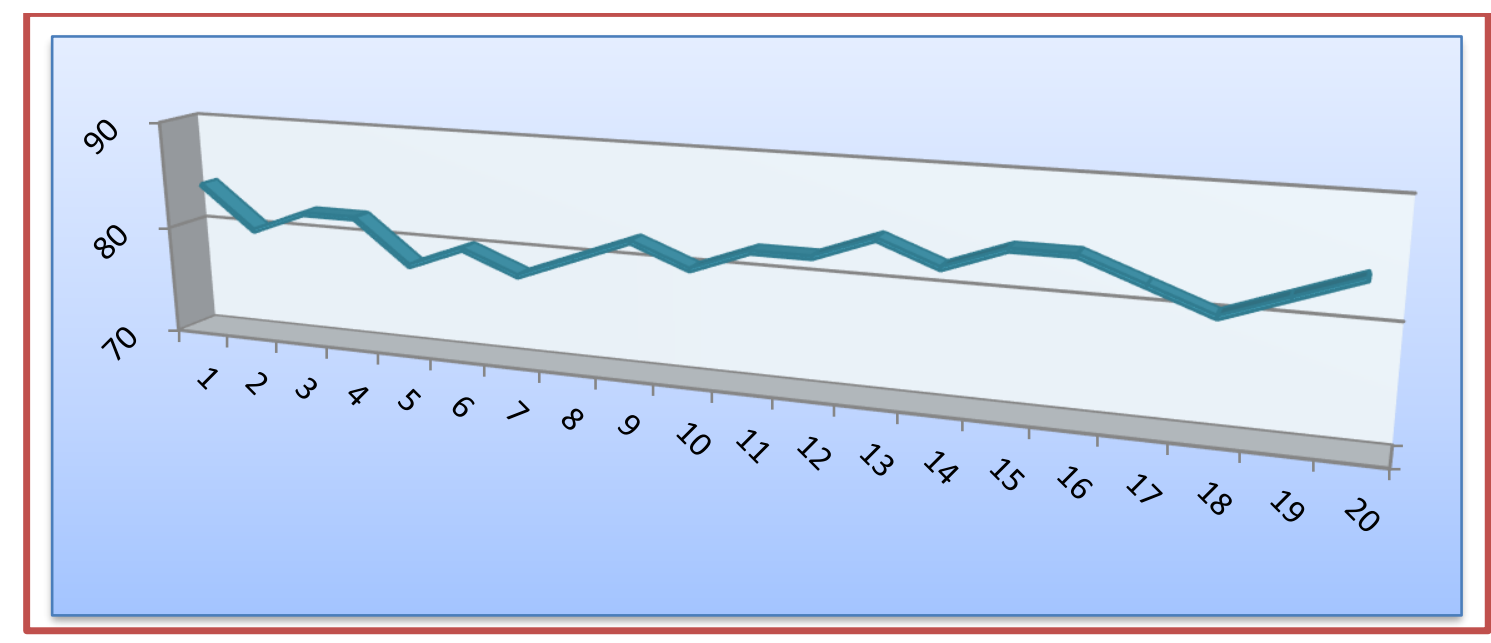

Figure (5)

Track of proposed training loads dynamics during the part of competition (2)

Section three: match training on motor performance for Gojushisho-sho as a whole for qualifiers.

This performance was executed during the third section of competition exercises of the main part, the game training on motor performance with gradual increase. Intensity of this section ranged from (90-98\%) in period of (13570 seconds) with percentage of (22.56\%) of the overall time of the proposed program. This included specific training duty "Internationally rated dynamic package in terms of speed, force and direction of performance". This motor package under study is fixed with time of actual performance, and compliance on performance of the international training lo characteristics in terms of speed, force and motor timing, maintenance of the principle of individual rating of player and maintenance of the dynamics of grading of 
proposed loads. This part was executed as training packages each of which contained 2 qualifiers:

- First Qualifier: During this qualifier the player performs the motor package (Goju. Shi hodai. kata) twice consecutively with the intensity rated in accordance with the actual time of the player's performance taking into account that there shall not be time intervals between repetition.

- Second qualifier: During it the player performs the motor package (Goju. Shisho. Dai. Kata) for one time with use of anaerobic work in this section with use of high intensity less than maximum as in figure (6)

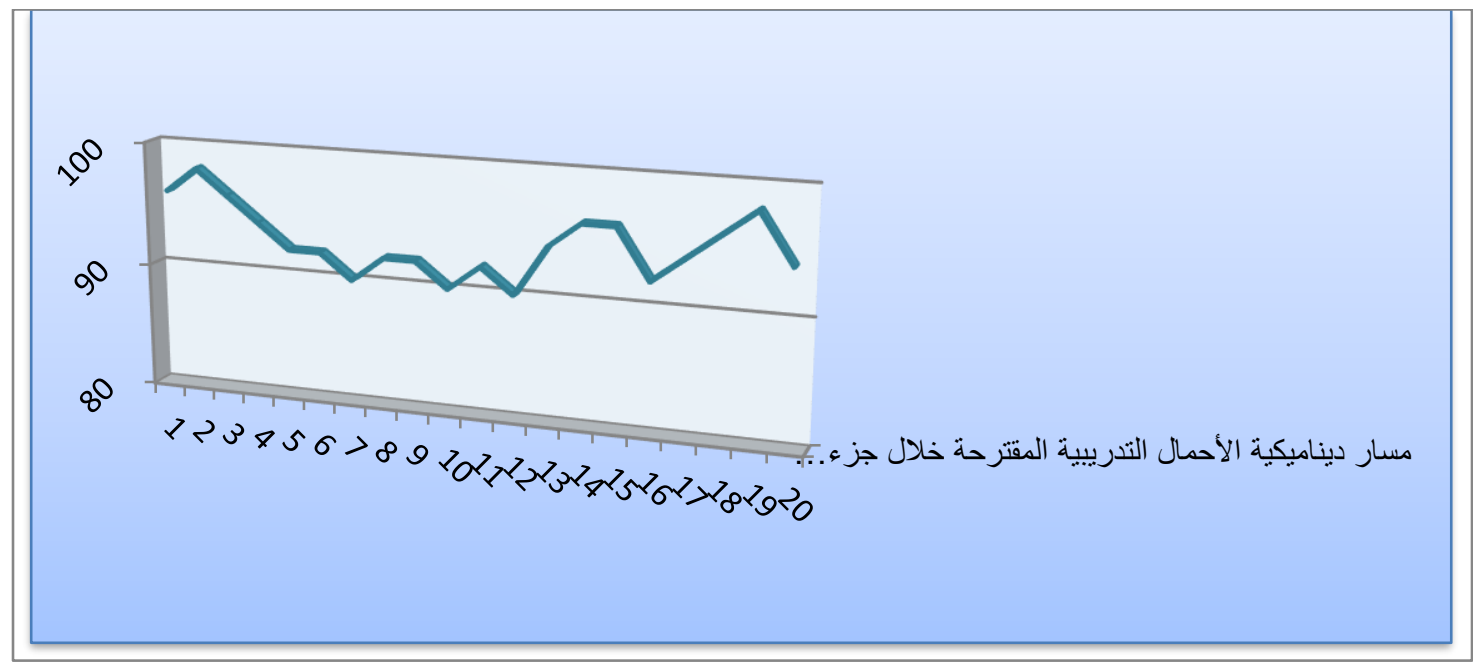

Figure (6)

Track of proposed training loads dynamics during the match training

\section{Final part}

This final part (recovery-warm down) included time of (6000 seconds) with percentage of $(9.97 \%)$ of the overall time for execution of the proposed los. It was taken into account that this section contains exercises to contribute to speed up recovery of side effects. And was executed in accordance with the functional aerobic direction through the content of weight exercises of all types and rotation of arms, waist and legs, respiration and recovery exercises of the working systems. The training intensity ranged between (30-40\%) with use of less than moderate and moderate intensity. 
Table (5) properties of proposed training los without use of the track of monthly biorhythm curves during the period of application of the program to the same under study

\begin{tabular}{|c|c|c|c|c|c|c|c|c|c|c|c|c|c|}
\hline \multirow{3}{*}{$\frac{n}{ \pm}$} & \multirow{3}{*}{$\begin{array}{l}\frac{0}{z} \\
0 \\
\frac{0}{z} \\
\frac{0}{0} \\
\sum\end{array}$} & \multicolumn{4}{|c|}{ Preparatory part } & \multicolumn{6}{|c|}{ Main part } & \multirow{2}{*}{\multicolumn{2}{|c|}{$\begin{array}{l}\text { Final part } \\
\text { (warm } \\
\text { down) }\end{array}$}} \\
\hline & & \multicolumn{2}{|c|}{ Warm up } & \multicolumn{2}{|c|}{\begin{tabular}{|c|} 
Special physica \\
preparation
\end{tabular}} & \multicolumn{2}{|c|}{$\begin{array}{l}\text { Competition } \\
\text { exercises (1) }\end{array}$} & \multicolumn{2}{|c|}{$\begin{array}{l}\text { Competition } \\
\text { exercises (2) }\end{array}$} & \multicolumn{2}{|c|}{$\begin{array}{l}\text { Match } \\
\text { training }\end{array}$} & & \\
\hline & & 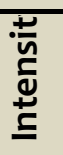 & $\begin{array}{l}\text { ํํㄱ } \\
\text { 는 }\end{array}$ & 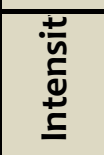 & ŏ & 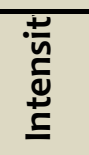 & 产 & 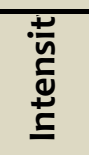 & ํㅡㅁ & 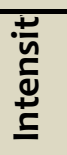 & $\begin{array}{l}\text { जू } \\
\frac{0}{3} \\
\text { 는 }\end{array}$ & 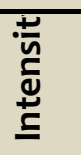 & $\begin{array}{l}\text { ज̆ } \\
\text { ํํㄴ }\end{array}$ \\
\hline \multirow{5}{*}{ 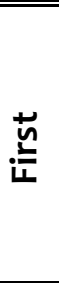 } & 1 & 40 & 1 & 62 & 2 & 72 & 1 & 84 & 1 & 96 & 1 & 30 & 1 \\
\hline & 2 & 40 & 1 & 64 & 2 & 74 & 2 & 80 & 2 & 98 & 2 & 32 & 1 \\
\hline & 3 & 42 & $\mathbf{1}$ & 66 & $\mathbf{1}$ & 74 & $\mathbf{1}$ & 82 & 1 & 96 & 1 & 30 & 1 \\
\hline & 4 & 44 & 1 & 66 & 3 & 76 & 3 & 82 & 2 & 94 & 2 & 32 & 1 \\
\hline & 5 & 40 & 1 & 64 & 2 & 72 & 2 & 78 & 1 & 92 & 1 & 32 & 1 \\
\hline \multirow{5}{*}{ 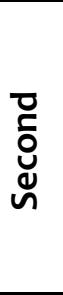 } & 6 & 40 & 1 & 64 & 2 & 70 & 2 & 80 & 2 & 92 & 1 & 34 & 1 \\
\hline & 7 & 40 & 1 & 66 & 1 & 72 & 3 & 78 & 1 & 90 & 2 & 34 & 1 \\
\hline & 8 & 40 & 1 & 66 & 2 & 74 & 2 & 80 & 2 & 92 & 2 & 40 & 1 \\
\hline & 9 & 45 & 1 & 68 & 1 & 76 & 3 & 82 & 2 & 92 & 2 & 34 & 1 \\
\hline & $\mathbf{1 0}$ & 40 & 1 & 64 & 2 & 74 & 2 & 80 & 1 & 90 & 1 & 34 & 1 \\
\hline \multirow{5}{*}{ 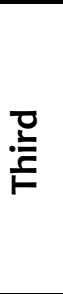 } & 11 & 45 & 1 & 64 & 2 & 72 & 2 & 82 & 2 & 92 & 1 & 36 & 1 \\
\hline & 12 & 45 & $\overline{1}$ & 66 & $\mathbf{1}$ & 76 & 3 & 82 & 1 & 90 & 2 & 34 & 1 \\
\hline & 13 & 45 & 1 & 68 & 3 & 80 & 1 & 84 & 2 & 94 & 2 & 34 & 1 \\
\hline & 14 & 45 & 1 & 68 & 1 & 76 & 3 & 82 & 2 & 96 & 1 & 36 & 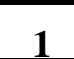 \\
\hline & 15 & 42 & 1 & 70 & 1 & 80 & 1 & 84 & 1 & 96 & 2 & 34 & \\
\hline \multirow{5}{*}{ 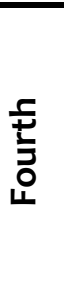 } & 16 & 40 & 1 & 68 & 2 & 76 & 3 & 84 & 1 & 92 & 1 & 38 & 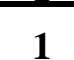 \\
\hline & 17 & 40 & 1 & 66 & 1 & 78 & 2 & 82 & 2 & 94 & 2 & 36 & 1 \\
\hline & 18 & 42 & 1 & 70 & 1 & 80 & 1 & 80 & 1 & 96 & 1 & 36 & 1 \\
\hline & 19 & 40 & 1 & 68 & 2 & 80 & 2 & 82 & 1 & 98 & 1 & 38 & 1 \\
\hline & 20 & 40 & 1 & 70 & 1 & 78 & 3 & 84 & 2 & 94 & 1 & 34 & \\
\hline
\end{tabular}


Table (6) properties of grading of proposed training los using the track of monthly biorhythm curves during the period of application of the program to the sample under study

\begin{tabular}{|c|c|c|c|c|c|c|c|c|c|c|c|c|c|}
\hline \multirow{3}{*}{$\stackrel{\tilde{\nu}}{\tilde{J}}$} & \multirow{3}{*}{$\begin{array}{l}\stackrel{0}{z} \\
\frac{0}{J} \\
\frac{\partial}{0} \\
\sum\end{array}$} & \multicolumn{4}{|c|}{ Preparatory part } & \multicolumn{6}{|c|}{ Main part } & \multirow{2}{*}{\multicolumn{2}{|c|}{$\begin{array}{l}\text { Final par } \\
\text { (warm } \\
\text { down) }\end{array}$}} \\
\hline & & \multicolumn{2}{|c|}{ Warm up } & \multicolumn{2}{|c|}{$\begin{array}{c}\text { Special physic } \\
\text { preparation }\end{array}$} & \multicolumn{2}{|c|}{$\begin{array}{c}\text { Competitio } \\
\text { exercises } \\
\text { (1) }\end{array}$} & \multicolumn{2}{|c|}{$\begin{array}{l}\text { Competition } \\
\text { exercises (2) }\end{array}$} & \multicolumn{2}{|c|}{$\begin{array}{l}\text { Match } \\
\text { training }\end{array}$} & & \\
\hline & & 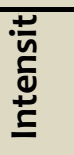 & 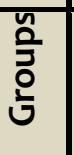 & 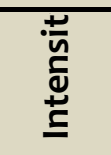 & 음 & 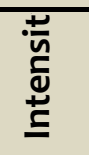 & $\begin{array}{l}\text { 少 } \\
\frac{0}{v} \\
\text { ㄴ. }\end{array}$ & 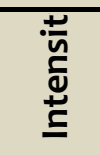 & $\begin{array}{l}\text { पू̃ } \\
\text { ㅎํㄴ }\end{array}$ & 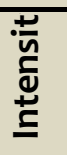 & 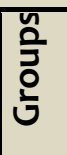 & 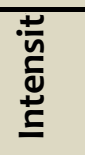 & 䘫 \\
\hline \multirow{5}{*}{$\stackrel{\hbar}{\grave{n}}$} & 1 & 40 & 1 & 62 & 2 & 72 & 1 & 84 & 1 & 96 & 1 & 30 & \\
\hline & 2 & 40 & 1 & 64 & 2 & 74 & 2 & 80 & 2 & 98 & 2 & 32 & 1 \\
\hline & 3 & 42 & 1 & 66 & 1 & 74 & 1 & 82 & 1 & 96 & 1 & 30 & 1 \\
\hline & 4 & 44 & 1 & 66 & 3 & 76 & 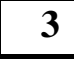 & 82 & 2 & 94 & 2 & 32 & 1 \\
\hline & 5 & 40 & 1 & 64 & 2 & 72 & 2 & 78 & 1 & 92 & 1 & 32 & \\
\hline \multirow{5}{*}{ סृ } & 6 & 40 & 1 & 64 & 2 & 70 & 2 & 80 & 2 & 92 & 1 & 34 & \\
\hline & 7 & 40 & $\mathbf{1}$ & 66 & 1 & 72 & 3 & 78 & 1 & 90 & 2 & 34 & \\
\hline & 8 & 40 & $\mathbf{1}$ & 66 & 2 & 74 & 2 & 80 & 2 & 92 & 2 & 40 & \\
\hline & 9 & 45 & 1 & 68 & 1 & 76 & 3 & 82 & 2 & 92 & 2 & 34 & 1 \\
\hline & 10 & 40 & $\mathbf{1}$ & 64 & 2 & 74 & 2 & 80 & 1 & 90 & 1 & 34 & 1 \\
\hline \multirow{5}{*}{ 站 } & 11 & 45 & $\mathbf{1}$ & 64 & 2 & 72 & 2 & 82 & 2 & 92 & 1 & 36 & - \\
\hline & 12 & 45 & 1 & 66 & 1 & 76 & 3 & 82 & 1 & 90 & 2 & 34 & 1 \\
\hline & 13 & 45 & 1 & 68 & 3 & 80 & 1 & 84 & 2 & 94 & 2 & 34 & 1 \\
\hline & 14 & 45 & 1 & 68 & 1 & 76 & 3 & 2 & 2 & 96 & 1 & 36 & 1 \\
\hline & 15 & 42 & 1 & 70 & 1 & 80 & 1 & 4 & 1 & 96 & 2 & 34 & 1 \\
\hline \multirow{5}{*}{ 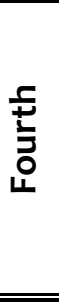 } & 16 & 40 & 1 & 68 & 2 & 76 & 3 & 84 & 1 & 92 & 1 & 38 & 1 \\
\hline & 17 & 40 & 1 & 66 & 1 & 78 & 2 & 82 & 2 & 94 & 2 & 36 & 1 \\
\hline & 18 & 42 & 1 & 70 & 1 & 80 & 1 & 80 & 1 & 96 & 1 & 36 & 1 \\
\hline & 19 & 40 & 1 & 68 & 2 & 80 & 2 & 82 & 1 & 98 & 1 & 38 & 1 \\
\hline & 20 & 40 & 1 & 70 & 1 & 78 & 3 & 84 & 2 & 94 & 1 & 34 & \\
\hline
\end{tabular}

\section{Statistic treatments}

The researcher used the Statistic Package of Social Science (SPSS) for statistical processing of data, and applied the following statistic means: 
Arithmetic means, Median, Standard deviation, Skewness coefficient, T-test, Simple

Pearson's correlation Coefficient, Improvement rates by percentage.

The researcher was satisfied with statistic significance level of (0.05)

\section{Presentation and discussion of results:}

Table (7) Percentages of improvement between the average (pre- post) measurements in the variables of special motor skills under study

\begin{tabular}{|c|c|c|c|c|c|c|c|c|c|c|}
\hline & \multirow[b]{2}{*}{ Variables } & \multirow{2}{*}{$\begin{array}{ll}\stackrel{0}{E} & \\
\frac{0}{0} & \frac{0}{n} \\
\frac{0}{0} & 0 \\
0 & 0\end{array}$} & \multirow{2}{*}{$\begin{array}{c}\text { Unit of } \\
\text { Measurem } \\
\text { ent }\end{array}$} & \multicolumn{3}{|c|}{ Without rhythm } & \multicolumn{3}{|c|}{ Using rhythm } & \multirow{2}{*}{$\begin{array}{l}\text { Difference of } \\
\text { improvement }\end{array}$} \\
\hline & & & & 닌 & $\dot{\tilde{o}}$ & Improvement & $\cong$ & 范 & Improvement & \\
\hline \multirow{8}{*}{ 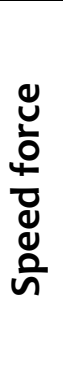 } & \multirow{2}{*}{ (Gayku.Zuki) } & Righ & No & 12 & 13 & $\% 8.33$ & 13 & 15 & $\% 15.38$ & $\% 7.05$ \\
\hline & & Left & No & 11 & 13 & $\% 18.18$ & 13 & 17 & $\% 30.77$ & $\% 12.59$ \\
\hline & \multirow{2}{*}{ (Oi.Zuki) } & Righ & No & 9 & 11 & $\% 22.22$ & 11 & 14 & $\% 27.27$ & $\% 5.05$ \\
\hline & & Left & No & 7 & 10 & $\% 42.86$ & 10 & 15 & $\% 50$ & $\% 7.14$ \\
\hline & \multirow[b]{2}{*}{ Ippon.Nukite) } & Righ & No & 8 & 10 & $\% 25.00$ & 10 & 15 & $\% 50$ & $\% 25.00$ \\
\hline & & Left & No & 7 & 9 & $\% 28.57$ & 9 & 14 & $\% 55.56$ & $\% 26.99$ \\
\hline & \multirow{2}{*}{ (Mae.Geri) } & Righ & No & 6 & 8 & $\% 33.33$ & 8 & 11 & $\% 37.50$ & $\% 4.17$ \\
\hline & & Left & No & 7 & 8 & $\% 14.29$ & 8 & 10 & $\% 25.00$ & $\% 10.71$ \\
\hline \multirow{8}{*}{ 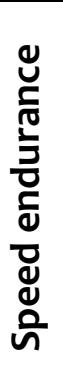 } & \multirow{2}{*}{ (Gayku.Zuki) } & Righ & No & 16 & 20 & $\% 25.00$ & 20 & 28 & $\% 40.00$ & $15.00 \%$ \\
\hline & & Left & No & 15 & 19 & $\% 26.67$ & 19 & 28 & $\% 47.37$ & $20.70 \%$ \\
\hline & \multirow{2}{*}{ (Oi.Zuki) } & Righ & No & 17 & 21 & $\% 23.53$ & 21 & 27 & $\% 28.57$ & $5.04 \%$ \\
\hline & & Left & No & 15 & 19 & $\% 26.67$ & 19 & 28 & $\% 47.37$ & $20.70 \%$ \\
\hline & \multirow[b]{2}{*}{ Ippon.Nukite) } & Righ & No & 14 & 17 & $\% 21.43$ & 17 & 25 & $\% 47.06$ & $25.63 \%$ \\
\hline & & Left & No & 11 & 16 & $\% 45.45$ & 16 & 25 & $\% 56.25$ & $10.80 \%$ \\
\hline & \multirow{2}{*}{ (Mae.Geri) } & Righ & No & 10 & 15 & $\% 50.00$ & 15 & 24 & $\% 60.00$ & $10.00 \%$ \\
\hline & & Left & No & 12 & 17 & $\% 41.67$ & 17 & 25 & $\% 47.06$ & $5.39 \%$ \\
\hline \multirow{8}{*}{ 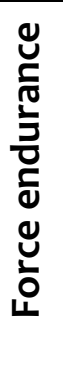 } & \multirow{2}{*}{ (Gayku.Zuki) } & Righ & No & 38 & 43 & $\% 13.16$ & 43 & 59 & $\% 37.21$ & $\% 24.05$ \\
\hline & & Left & No & 36 & 43 & $\% 19.44$ & 43 & 68 & $\% 58.14$ & $\% 38.70$ \\
\hline & \multirow{2}{*}{ (Oi.Zuki) } & Righ & No & 31 & 38 & $\% 22.58$ & 38 & 57 & $\% 50.00$ & $\% 27.42$ \\
\hline & & Left & No & 33 & 40 & $\% 21.21$ & 40 & 58 & $\% 45.00$ & $\% 23.79$ \\
\hline & \multirow[b]{2}{*}{ Ippon.Nukite) } & Righ & No & 34 & 41 & $\% 20.59$ & 41 & 58 & $\% 41.46$ & $\% 20.87$ \\
\hline & & Left & No & 29 & 38 & $\% 31.03$ & 38 & 57 & $\% 50.00$ & $\% 18.97$ \\
\hline & \multirow{2}{*}{ (Mae.Geri) } & Righ & No & 24 & 32 & $\% 33.33$ & 32 & 45 & $\% 40.63$ & $\% 7.30$ \\
\hline & & Left & No & 25 & 31 & $\% 24.00$ & 31 & 45 & $\% 45.16$ & $\% 21.16$ \\
\hline \multirow{8}{*}{ 言 } & \multirow{2}{*}{ (Gayku.Zuki) } & Righ & Sec. & 3.6 & 3.1 & $\% 17.52$ & 3.14 & 1.90 & $\% 39.49$ & $21.97 \%$ \\
\hline & & Left & Sec. & 3.8 & 3.2 & $\% 20.63$ & 3.20 & 1.88 & $\% 41.25$ & $20.62 \%$ \\
\hline & \multirow{2}{*}{ (Oi.Zuki) } & Righ & Sec. & 3.8 & 3.0 & $\% 27.33$ & 3.00 & 2.06 & $\% 31.33$ & $\% 4.00$ \\
\hline & & Left & Sec. & 3.4 & 2.9 & $\% 18.62$ & 2.90 & 2.02 & $\% 30.34$ & $\% 11.72$ \\
\hline & \multirow[b]{2}{*}{ Ippon.Nukite) } & Righ & Sec. & 4. & 3.6 & $\% 10.16$ & 3.64 & 1.80 & $\% 50.55$ & $40.39 \%$ \\
\hline & & Left & Sec. & 3.3 & 2.7 & $\% 21.69$ & 2.72 & 1.65 & $\% 39.34$ & $17.65 \%$ \\
\hline & \multirow{2}{*}{ (Mae.Geri) } & Righ & Sec. & 6. & 6.2 & $\% 10.53$ & 6.27 & 4.74 & $\% 32.28$ & $\% 21.75$ \\
\hline & & Left & Sec. & 7.2 & 6.1 & $\% 17.80$ & 6.18 & 4.49 & $\% 37.64$ & $\% 19.84$ \\
\hline
\end{tabular}


Table (8) Percentages of improvement between the average (pre- post) measurements in the skill variables before the study

\begin{tabular}{|c|c|c|c|c|c|c|c|c|c|c|}
\hline \multirow{2}{*}{\multicolumn{2}{|c|}{$\begin{array}{c}\text { Variables under } \\
\text { study }\end{array}$}} & \multirow[b]{2}{*}{ 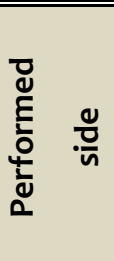 } & \multirow[b]{2}{*}{ 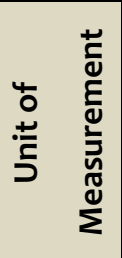 } & \multicolumn{3}{|c|}{ Without rhythm } & \multicolumn{3}{|c|}{ Using rhythm } & \multirow[b]{2}{*}{$\begin{array}{l}\text { Difference } \\
\text { of } \\
\text { improvem } \\
\text { ent }\end{array}$} \\
\hline & & & & $\stackrel{0}{2}$ & 苋 & 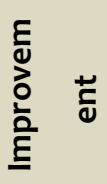 & $\stackrel{0}{2}$ & $\begin{array}{l}\text { ஸू } \\
\Omega\end{array}$ & 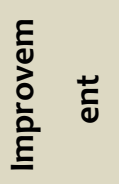 & \\
\hline \multirow{8}{*}{$\begin{array}{l}\frac{y}{x} \\
\frac{n}{\bar{n}} \\
\frac{\bar{n}}{n}\end{array}$} & \multirow{2}{*}{ (Gayku.Zuki) } & Right & Degree & 5.7 & 6.2 & $\% 8.77$ & 6.2 & 7.0 & $\% 12.90$ & $\% 4.13$ \\
\hline & & Left & Degree & 5.8 & 6.2 & $\% 6.90$ & 6.2 & 6.9 & $\% 11.29$ & $\% 4.39$ \\
\hline & \multirow{2}{*}{ (Oi.Zuki) } & Right & Degree & 5.8 & 6.3 & $\% 8.62$ & 6.3 & 6.9 & $\% 9.52$ & $\% 0.90$ \\
\hline & & Left & Degree & 5.9 & 6.2 & $\% 5.08$ & 6.2 & 6.9 & $\% 11.29$ & $\% 6.21$ \\
\hline & \multirow{2}{*}{ (Ippon.Nukite) } & Right & Degree & 5.9 & 6.1 & $\% 3.39$ & 6.1 & 6.9 & $\% 13.11$ & $\% 9.72$ \\
\hline & & Left & Degree & 5.7 & 6.2 & $\% 8.77$ & 6.2 & 6.8 & $\% 9.68$ & $\% 0.91$ \\
\hline & \multirow{2}{*}{ (Mae.Geri) } & Right & Degree & 5.8 & 6.1 & $\% 5.17$ & 6.1 & 7.0 & $\% 14.75$ & $\% 9.58$ \\
\hline & & Left & Degree & 5.8 & 6.2 & $\% 6.89$ & 6.2 & 7.0 & $\% 12.90$ & $\% 6.01$ \\
\hline \multirow{3}{*}{ مِ } & \multicolumn{2}{|l|}{ First } & Degree & 5.9 & 6.1 & $\% 3.39$ & 6.1 & 6.9 & $\% 13.11$ & $\% 9.72$ \\
\hline & \multicolumn{2}{|l|}{ Second } & Degree & 5.8 & 6.3 & $\% 8.62$ & 6.3 & 6.8 & $\% 7.94$ & $\% 0.68$ \\
\hline & \multicolumn{2}{|l|}{ Third } & Degree & 5.8 & 6.1 & $\% 5.17$ & 6.1 & 7.0 & $\% 14.75$ & $\% 9.58$ \\
\hline$\frac{n}{0}$ & \multicolumn{2}{|l|}{ Fourth } & Degree & 5.7 & 6.1 & $\% 7.02$ & 6.1 & 6.8 & $\% 11.48$ & $\% 4.46$ \\
\hline \multicolumn{3}{|c|}{ Time of performance of motor } & Sec. & 118 & 120 & $\% 1.67$ & 120 & 125 & $\% 4.17$ & $\% 2.50$ \\
\hline \multicolumn{3}{|c|}{ Standard of motor package } & Degree & 5.8 & 6.1 & $\% 5.17$ & 6.1 & 7.1 & $\% 16.39$ & $\% 11.22$ \\
\hline
\end{tabular}

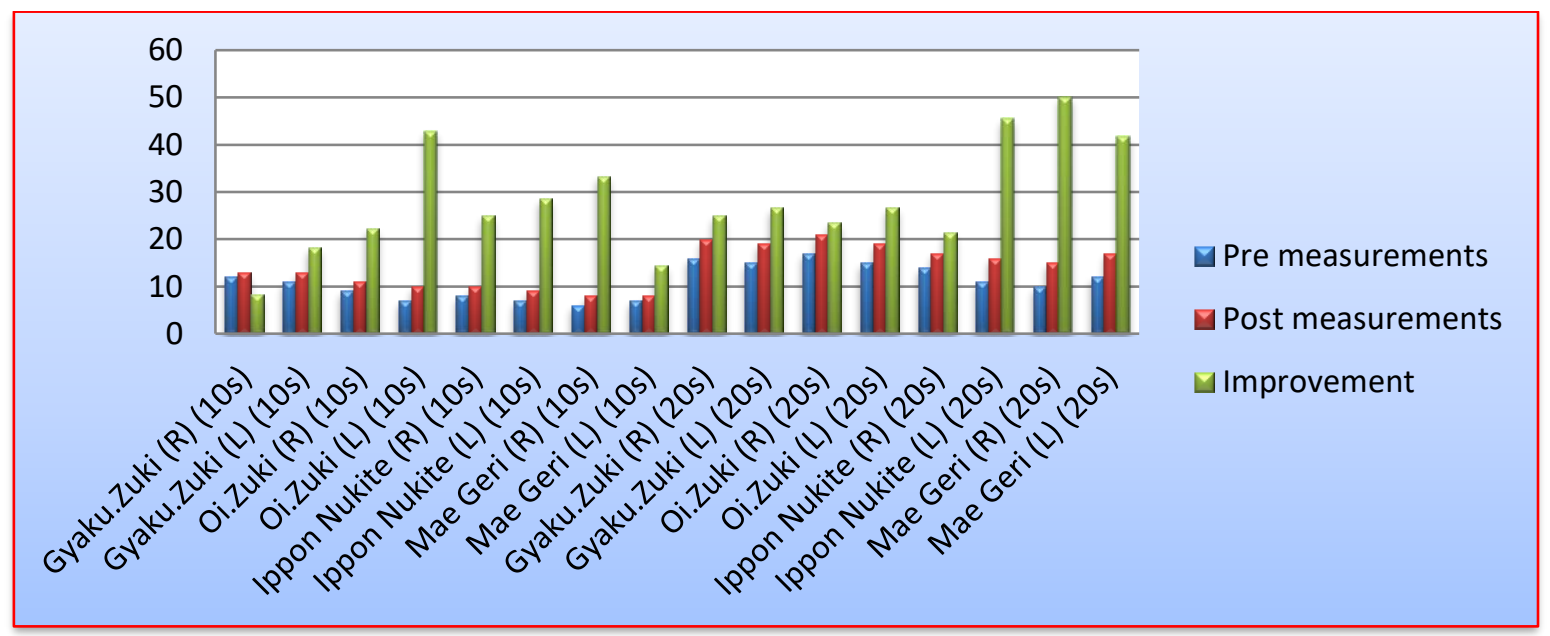

Figure (7)

Percentages of improvement between the pre and post measurements without use of biorhythm curves in the variables of special motor capacities under study 


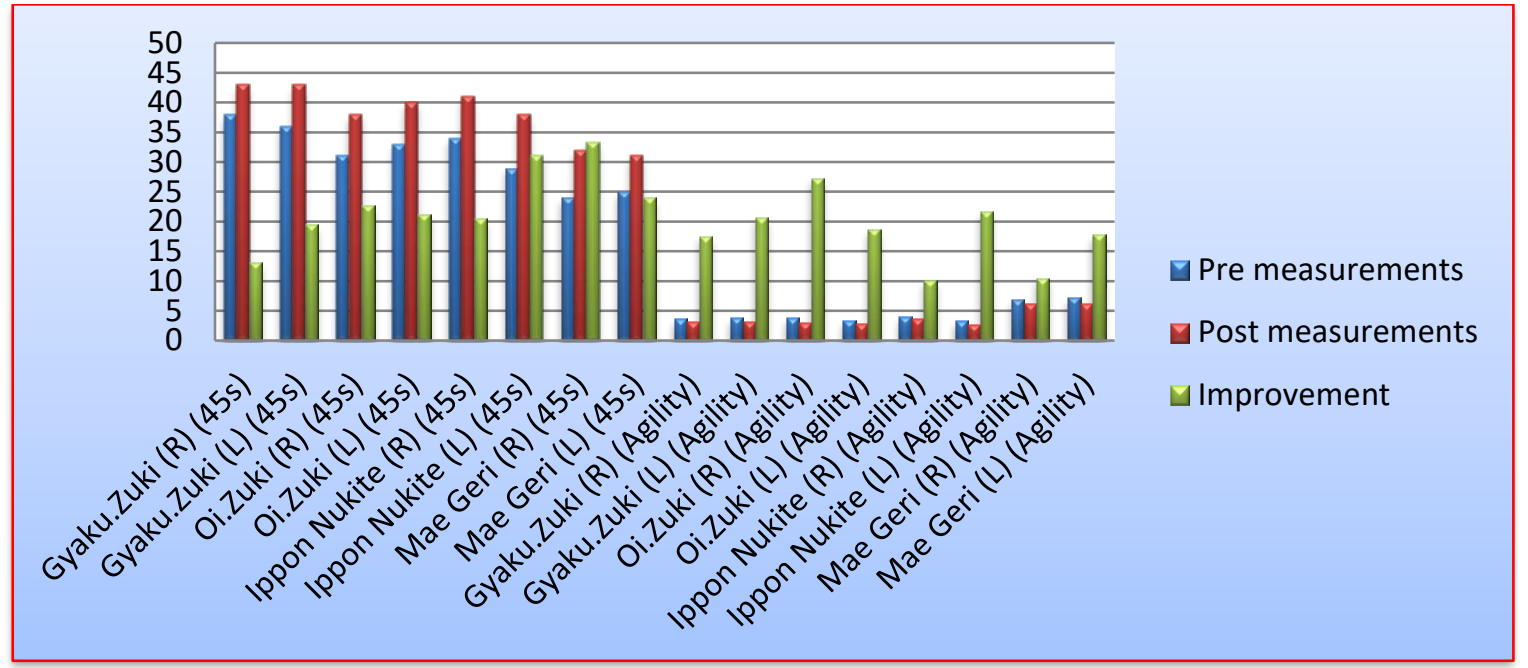

Figure (8)

Percentages of improvement between the pre and post measurements without use of biorhythm curves in the variables of special motor capacities under study

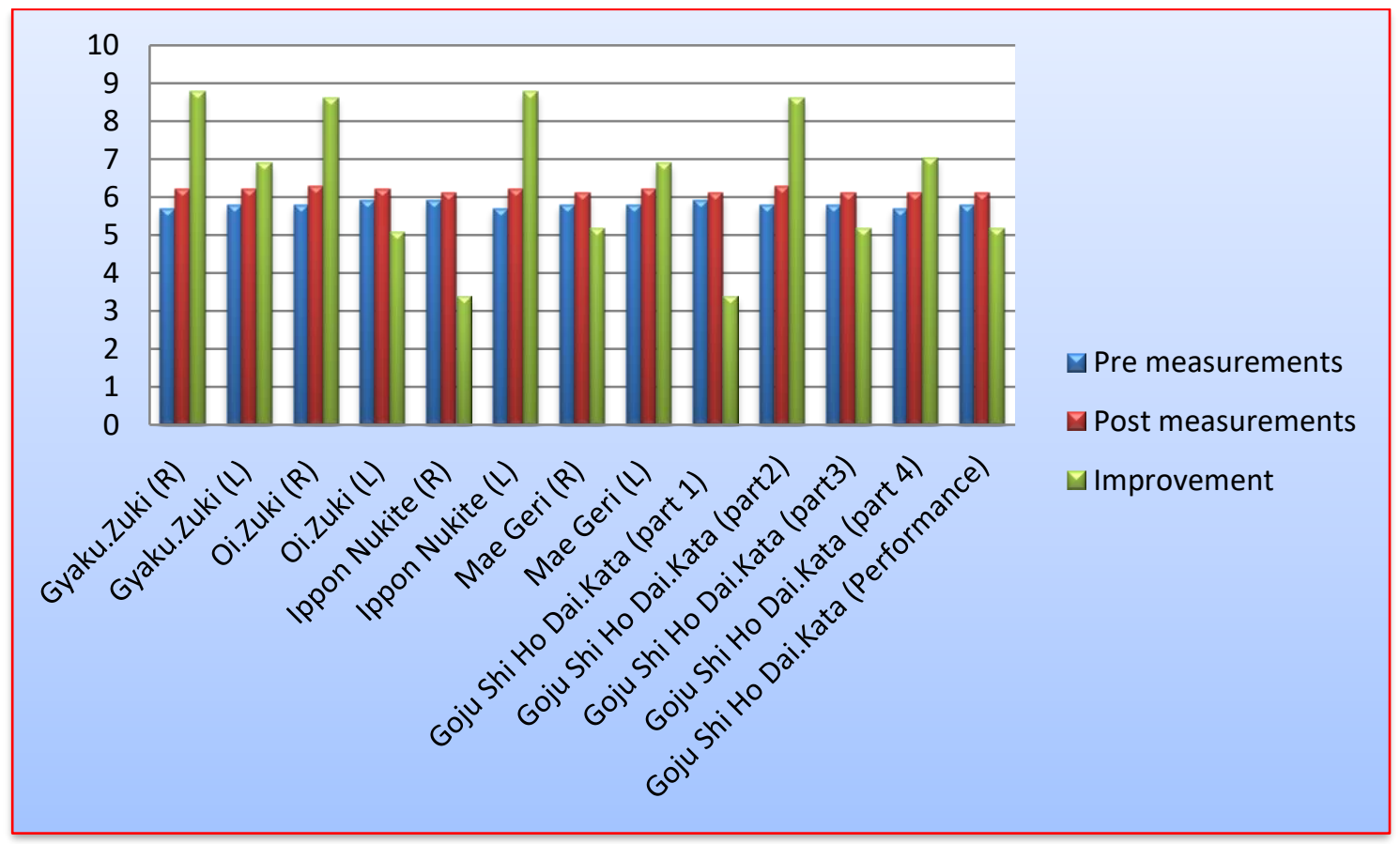

Figure (9)

Percentages of improvement between the pre and post measurements without use of biorhythm curves in the skill variables under study 


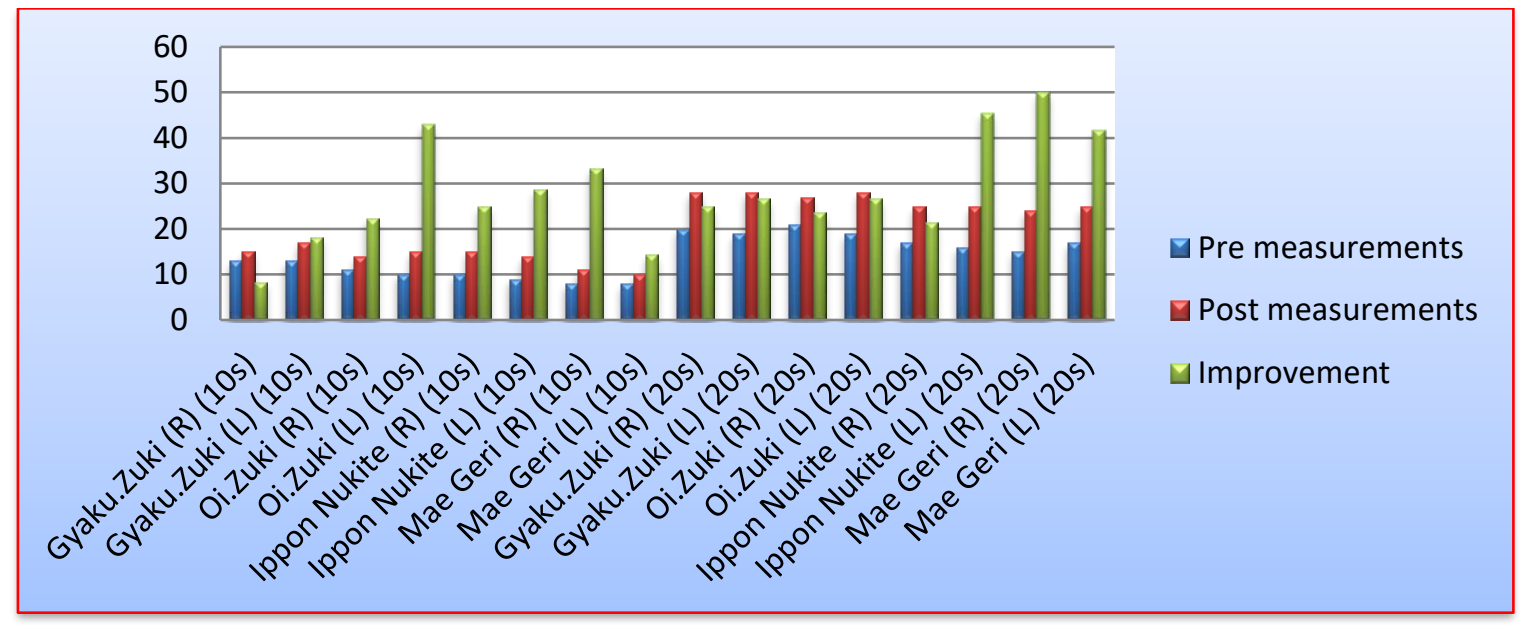

Figure (10)

Percentages of improvement between the pre and post measurements with use of biorhythm curves in the variables of special motor capacities under study

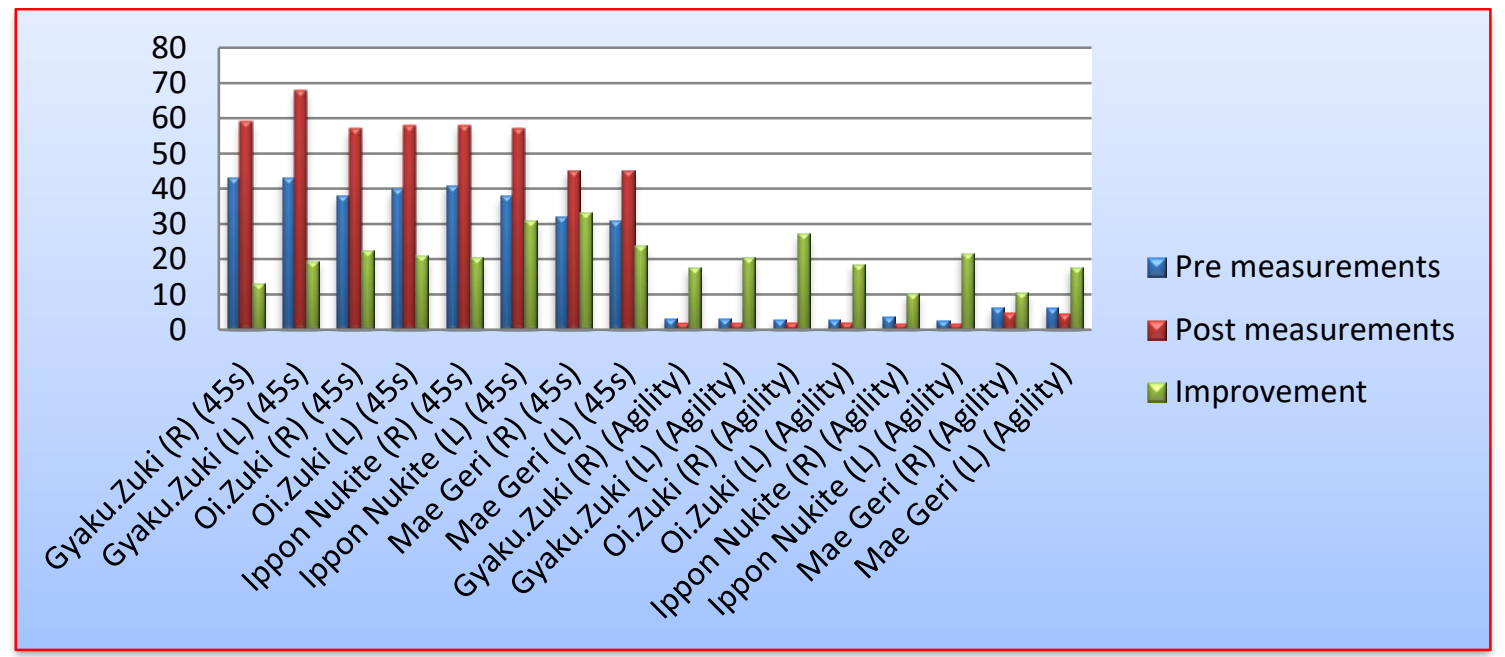

Figure (11)

Percentages of improvement between the pre and post measurements with use of biorhythm curves in the variables of special motor capacities under study 


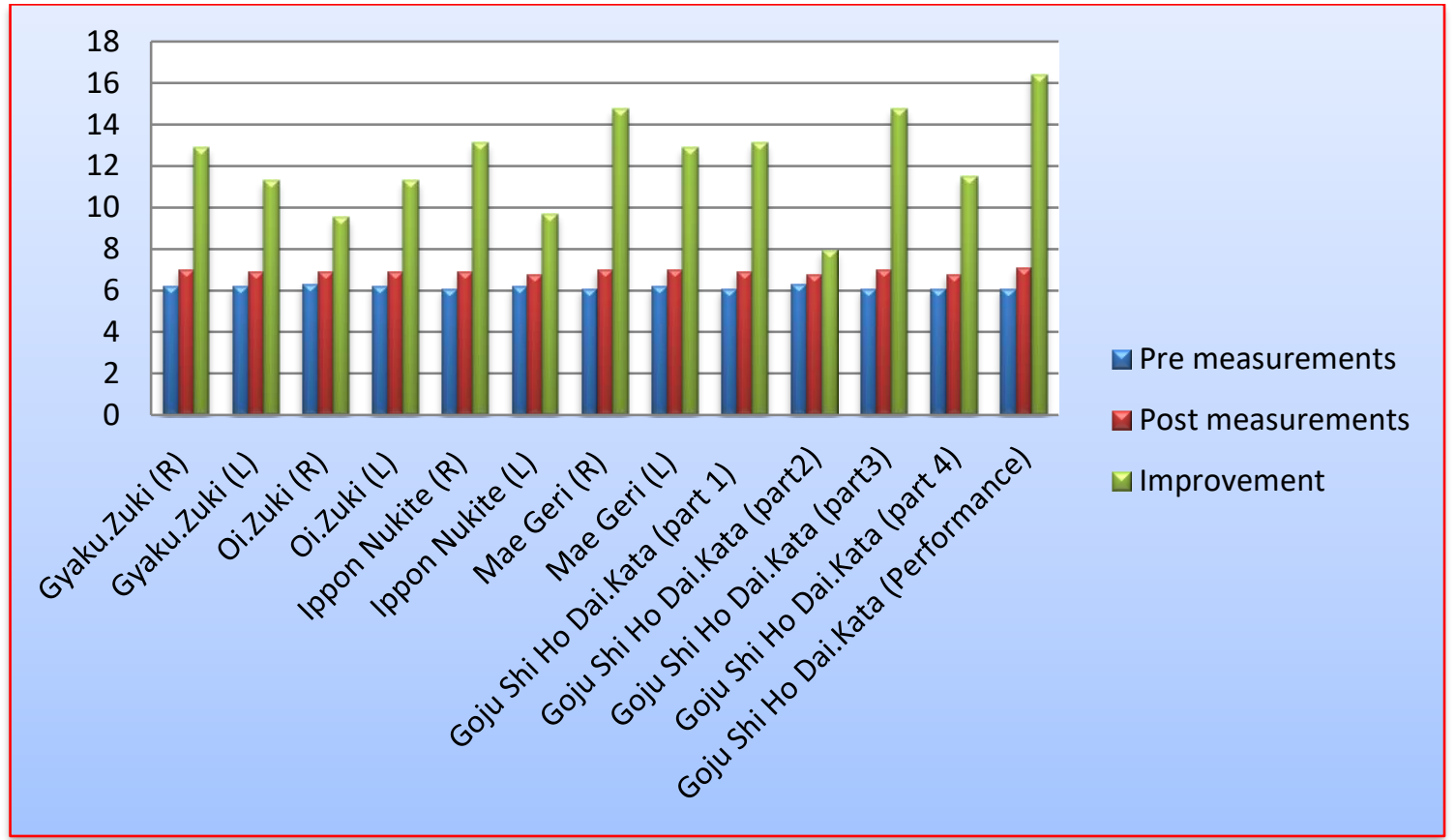

Figure (12)

Percentages of improvement between the pre and post measurements with use of biorhythm curves in the skill variables under study

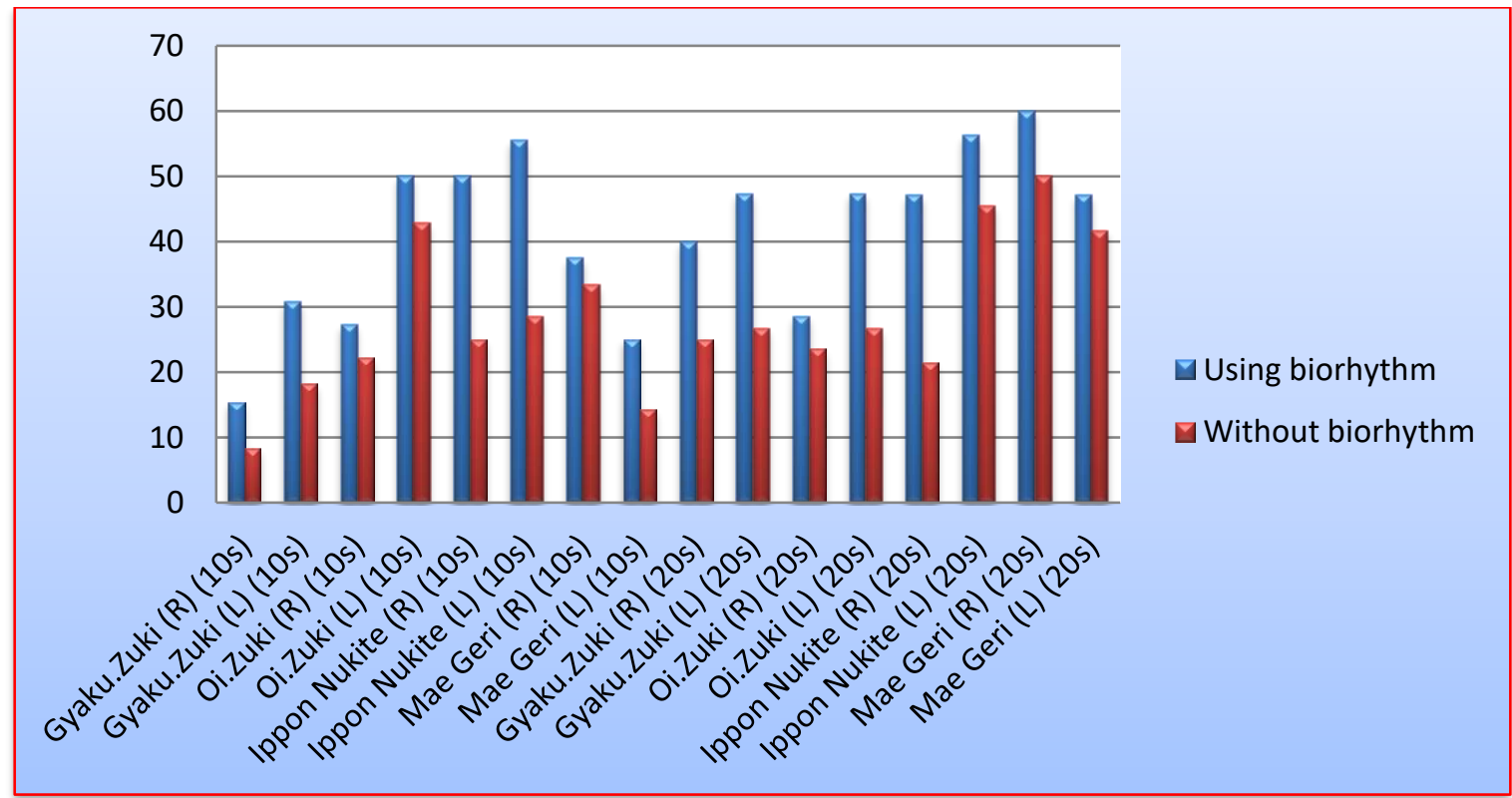

Figure (7)

Percentages of improvement between the use of biorhythm curves without use of biorhythm curves in the variables of special motor capacities under study 


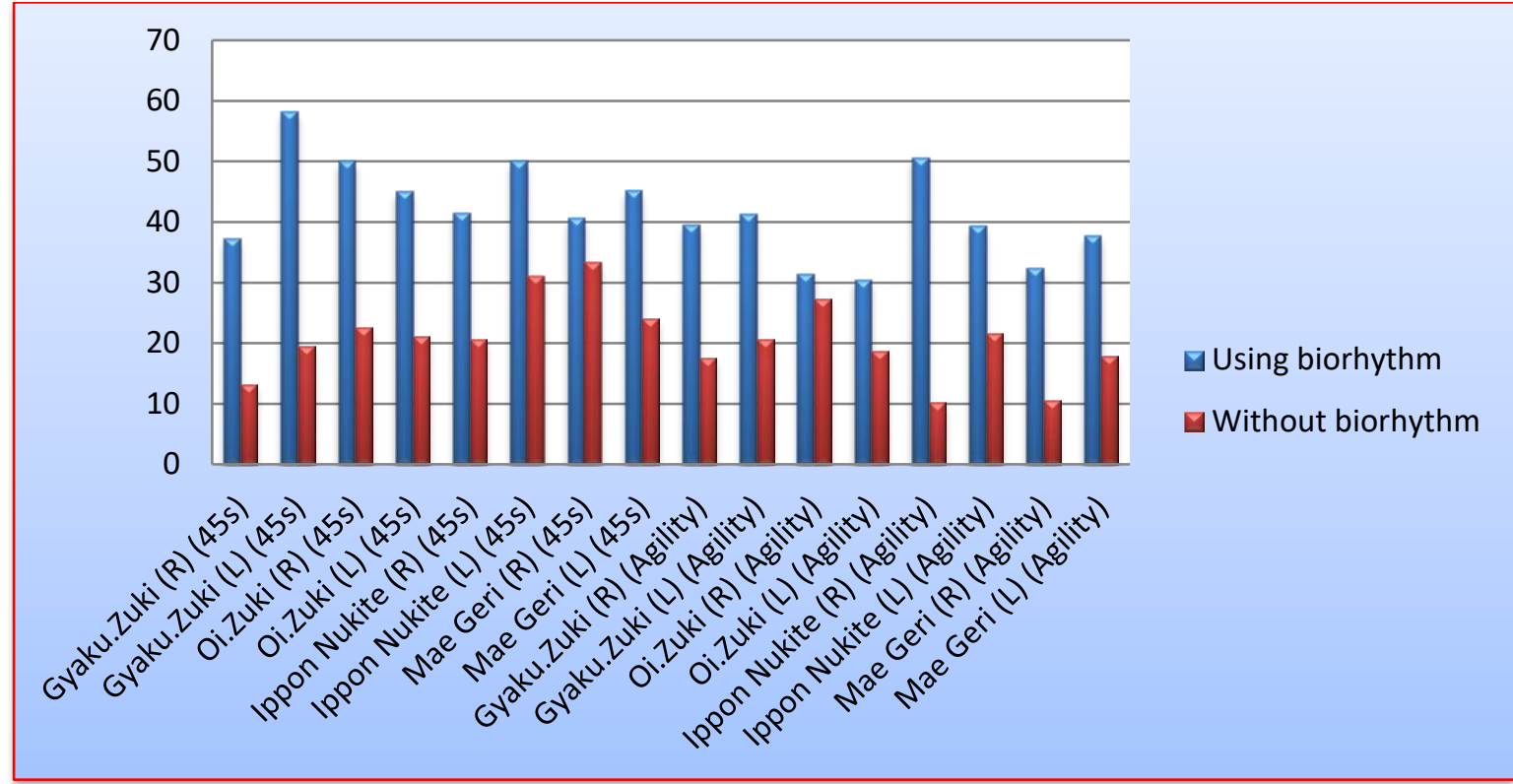

Figure (8)

Percentage of improvement between the use of biorhythm curves- without use of biorhythm curves in the variables of special motor capacities under study

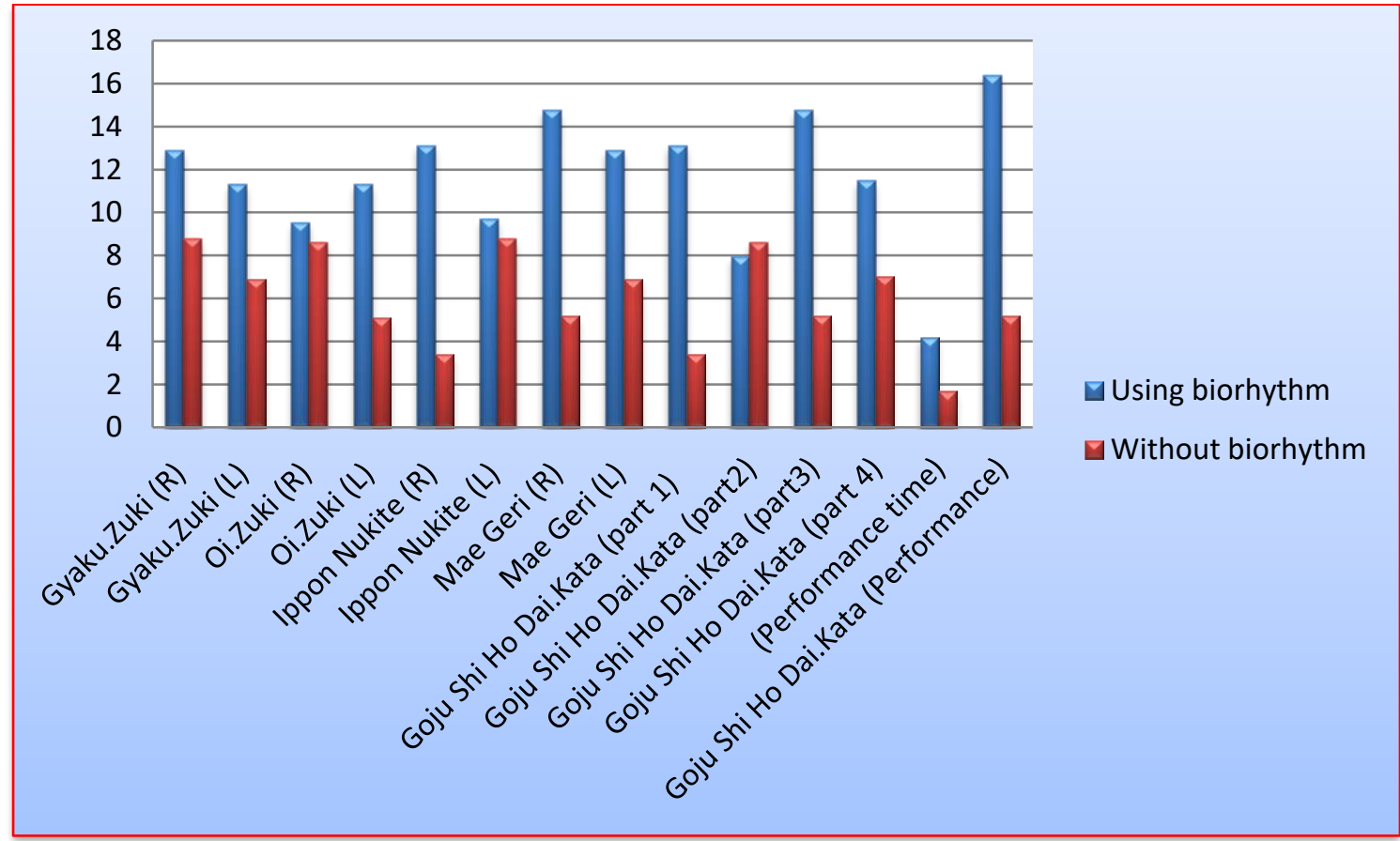

Figure (9)

Percentage of improvement between (use of biorhythm curves- without use of biorhythm curves) in the skill variables under study 
Data of table (7) and figures (7) , (8), (9) indicate that there are statistically significant differences between the pre and post measurements of the variables of special motor capacities under study for the player of the study without use of biorhythm curves as follows:

- Variable of speed force in Gayku. Zuki. The percentage of improvement between the average pre and post measurements was $(8.33 \%)$ and (18.18\%) for performance with the right and left sides respectively.

- Variable of speed force of Oi. Zaku. The percentage of improvement in the average pre and post measurements was $(22.22 \%)$ and $(42.86 \%)$ of performance with the right side and left side respectively.

- Variable of speed force of one-finger spear-hand (Ippon. Nukite). The percentage of improvement between the average pre and post measurements was $(25.00 \%)$ and (28.57\%) for performance in the left and right sides respectively:

- Variable of speed force of the front kick (Mae. Geri). The percentage of improvement between the pre and post measurements was (33.33\%) and (14.29\%) for performance with the right side and left side respectively.

- Variable of speed endurance of the reverse straight punch (Gayku. Zuki). The percentage of improvement between the pre measurement and post measurement was $(25.00 \%)$ and $(26.67 \%)$ for performance with the right side and left side respectively.

- Variable of special speed endurance of the straight long punch (Oi. Zuki) and the percentage of improvement between the average pre and post measurements was (23.53\%) and (26.67\%) for performance with the right side and left side respectively.

- Variable of one-finger spear-hand (Ippon. Nukite) and the percentage of improvement between the average pre and post measurements was (21.43\%) and (45.45\%) for performance with the right side and left side respectively.

- Variable of speed endurance of the front kick (Mai. Geri) and the percentage of improvement between the average pre and post measurements was (50.33\%) and $(41.67 \%)$ for performance with the right side and left side respectively.

- Variable of straight reverse punch endurance (Gayku. Zuki) and the percentage of improvement between the average pre and post measurements was (13.16\%) and (19.44\%) for performance with the right side and left side respectively.

- Variable of speed endurance of straight long punch (Oi. Zuki) and the percentage of improvement between the average pre and post measurements was $(22.58 \%)$ and $(21.21 \%)$ for performance with the right side and left side respectively. 
- Variable of one-finger spear-hand (Ippon. Nukite) and the percentage of improvement between the average pre and post measurements was (20.59\%) and (31.03\%) for performance with the right side and left side respectively.

- Variable of front kick force endurance (Mai. Geri) and the percentage of improvement between the average pre and post measurements was (33.33\%) and (24.00\%) for performance with the right side and left side respectively.

- Variable of agility of straight reverse punch (Gayku. Zuki) and the percentage of improvement between the average pre and post measurements was (17.52\%) and $(20.63 \%)$ for performance with the right side and left side respectively.

- Variable of agility of straight long punch (Oi. Zuki) and the percentage of improvement between the average pre and post measurements was (27.33\%) and (18.62\%) for performance with the right side and left side respectively.

- Variable of agility of one-finger spear-hand (Ippon. Nukite) and the percentage of improvement between the average pre and post measurements was (10.16\%) and (21.69\%) for performance with the right side and left side respectively.

Variable of agility of front kick (Mae. Geri) and the percentage of improvement between the average pre and post measurements was (10.53\%) and (17.80\%) for performance with the right side and left side respectively.

There appeared statistically significant differences between the pre measurement and post measurement of the values of skill variables under study for the player of the study without use of biorhythm curves as follows:

- Average of skill style of straight reverse punch (Gayku. Zuki), and the percentage of improvement between the average pre and post measurements was (8.77\%) and (6.90\%) for performance with the right side and left side respectively.

- Variable of performance of skill style of the straight long punch (Oi. Zuki), and the percentage of improvement between the average pre and post measurements was $(8.62 \%)$ and $(5.08 \%)$ for performance with the right side and left side respectively.

- Variable of performance standard of skill performance of one-finger spear-hand (Ippon. Nukite) and the percentage of improvement between the average pre and post measurements was $(3.39 \%)$ and $(8.77 \%)$ for performance with the right side and left side respectively.

- Variable of performance level of front kick (Mai. Geri) and the percentage of improvement between the average pre and post measurements was (5.17\%) and (6.89\%) for performance with the right side and left side respectively. 
- Variable of performance level of skill style of training packages that consist of the structure of dynamic package (kata) under study, and the percentage of improvement between the average pre and post measurements was (3.39\%), (8.62\%), (5.17\%) and (7.02\%) for the four training packages respectively.

- Variable of performance time and skill performance level of the motor package (kata) under study, and the percentage of improvement between the average pre and post measurements was $(1.67 \%)$ and $(5.17 \%)$ for the performance time and standard respectively.

The researcher attribute the positive percentage change of the level of special motor capacities of the player of the study to the properties of training los and means of rating and execution of them, in dition to direction of the player's capacities. This was reflected on the percentage of effect. In dition, the researcher believes that variance in the percentage of improvement between the special motor skills under study is attributed to the result of direction of the content of training los properties on individual form to the player, in dition to rationalization of the training principles of privacy and direction in accordance with the individual grading of player, and the use of los implemented through similar exercises to the nature of performance and properties of motor performance used in the competition and comprising the structure of "kata" under study.

The researcher attributes the positive percentage change of performance level of individual skill styles and the average performance of training packages that comprise the structural performance of motor package (kata) under study to the proposed training program and the skill content of training units of exercises for individual competition and the special competition exercises of training packages where the motor track agrees with the motor tracks of motor package (kata) under study, in dition to the competition exercises and use of los implemented through exercises similar to the nature of performance and properties of motor performance used in the competition.

In dition, we note decrease of the values of positive percentage change of the variable of performance time of kata under study. This may be attributed to internationally recognized time for performance of each international kata package. This time is related to the motor rhythm of each motor package (kata). The research believes that these percentages are logical and they indicator of performance of motor package (kata) under study.

This is in agreement with the notes of Amal Farouk Ali (2009) (6)Walaa Hamdy Farghaly (2011) (15); Ahmed Mahmoud Ibrahim (2011) (4); Rania GaberTawfiq Ahmed (2011) (7); Saleh Abd elker Atris (2010) (9); , Heba Mohamed Ali (2012 ) (14)

Therefore, the first hypothesis of the study is satisfied. 
In dition, the data of table (7) and figure (10), (11) and (12) indicate that there are statistically significant differences between the pre measurement and post measurement of the values of variables of motor special motor capacity under study for the player of the study using the biorhythm curves as follows:

- Variable of speed force of the straight reverse punch (Gayku. Zuki). The percentage of improvement between the pre and post measurements was (15.38\%) and (30.77\%) for the right and left side performance respectively.

- Variable of speed performance of the straight long punch (Oi. Zuki). The percentage of improvement between the pre and post measurements was $(27.27 \%)$ and $(50.00 \%)$ for the right and left side performance respectively.

- Variable of speed force of one-finger spear-hand (Ippon. Nukite). The percentage of improvement between the pre and post measurements was $(50.00 \%)$ and $(55.56 \%)$ for the right and left side performance respectively.

- Variable of speed performance of front kick (Mae. Geri). The percentage of improvement between the pre and post measurements was $(37.50 \%)$ and $(25.00 \%)$ for the right and left side performance respectively.

- Variable for endurance of speed endurance of straight reverse punch (Gayku. Zuki). The percentage of improvement between the pre and post measurements was (40.00\%) and $(47.37 \%)$ for the right and left side performance respectively.

- Variable for speed endurance of straight long punch (Oi. Zuki). The percentage of improvement between the pre and post measurements was (28.57\%) and (47.37\%) for the right and left side performance respectively.

- Variable of speed endurance of one-finger spear-hand (Ippon. Nukite). The percentage of improvement between the pre and post measurements was (47.06\%) and (56.25\%) for the right and left side performance respectively.

- Variable of speed of front kick (Mae. Geri). The percentage of improvement between the pre and post measurements was (28.57\%) and (47.37\%) for the right and left side performance respectively.

- Variable of speed endurance of the straight reverse punch (Gayku. Zuki). The percentage of improvement between the pre and post measurements was (37.21\%) and $(58.14 \%)$ for the right and left side performance respectively.

- Variable of force endurance of the straight long punch (Oi. Zuki). The percentage of improvement between the pre and post measurements was (50.00\%) and (45.00\%) for the right and left side performance respectively. 
- Variable of force endurance of one-finger spear-hand (Ippon. Nukite). The percentage of improvement between the pre and post measurements was (41.46\%) and (50.00\%) for the right and left side performance respectively.I

- Variable of front kick force (Mae. Geri). The percentage of improvement between the pre and post measurements was $(40.63 \%)$ and (45.16\%) for the right and left side performance respectively.

- Variable of agility of straight reverse punch (Gayku. Zuki). The percentage of improvement between the pre and post measurements was $(39.49 \%)$ and $(41.25 \%)$ for the right and left side performance respectively.

- Variable of agility of straight long punch (Oi. Zuki). The percentage of improvement between the pre and post measurements was (31.33\%) and (30.34\%) for the right and left side performance respectively.

- Variable of agility of one-finger spear-hand (Ippon. Nukite). The percentage of improvement between the pre and post measurements was (50.55\%) and (39.34\%) for the right and left side performance respectively.

- Variable of agility of front kick (Mae. Geri). The percentage of improvement between the pre and post measurements was (32.28\%) and (37.64\%) for the right and left side performance respectively.

There are statistically significant differences between the pre measurement and post measurement of the special skill variables under study for the player of the study using the biorhythm curves as follows:

- Variable of skill performance of straight reverse punch (Gayku. zuki). The percentage of improvement between the pre and post measurements was (12.90\%) and (11.29\%) for the right and left side performance respectively.

- Variable performance standard of the skill style of straight long punch (Oi. Zuki). The percentage of improvement between the pre and post measurements was $(9.52 \%)$ and (11.29\%) for the right and left side performance respectively.

- Variable of performance standard of the skill style of one-finger spear-hand (Ippon. Nukite). The percentage of improvement between the pre and post measurements was $(13.11 \%)$ and $(9.68 \%)$ for the right and left side performance respectively.

- Variable of skill performance style of front kick (Mae. Geri). The percentage of improvement between the pre and post measurements was $(14.75 \%)$ and $(12.90 \%)$ for the right and left side performance respectively.

- Variable of performance standard of the skill style of training packages that comprise the structure of motor package (kata) under study. The percentage of improvement 
between the pre and post measurements was (13.11\%), (7.94\%), (14.75\%), (11.48\%) for the four training packages respectively.

- Variable of time and standard of skill performance of the motor package (kata) under study. The percentage of improvement between the pre and post measurements was $(4.17 \%)$ and $(16.39 \%)$ for the right and left side performance respectively.

The researcher attributes the percentage change to the level of special motor capacities of the player of the study to the use of distribution of formation of training loads in the training program in accordance with biorhythm curves of the player, and properties of training los and methods of grading and execution of them, in dition to the direction of the player's capacities. This was reflected on the percentage of effect. In dition, the researcher believes that variance in the percentage of improvement between the special motor skills under study is due to the direction of the content of training lo characteristics individually for the player, in ditional to rationalization of the principles of training, including the privacy and development in accordance with the player's individual rating, and use of los executed through exercises similar to the nature of performance and characteristics of motor performance used in competition and composing the structure of "Kata" under study.

The researcher attributed the percentage positive change in the performance of individual skill styles and the performance of training packages that comprise the structure of "Kata" under study to the use of distribution of training lo formation in the training program in accordance with the player's biorhythm curves, and the skill content of the training units, including exercises of individual competition, and competition exercises of the training packages where the motor track is in line with the motor tracks of motor packages (Kata) under study, in dition to the exercises of competition and use of los enforced through similar exercises to the nature of performance and characteristics of motor performance applied in the competition.

Reduction of the values of percentage positive change of the variable of performance time of motor package (Kata) under study is noted. This may be attributed to internationally recognized time of performance of each motor package (Kata). This time is related to the motor rhythm of each motor package (kata). The researcher believes that this percentage is logical, and it is indicator of improvement of performance standard of motor package (Kata) under study.

This agrees with the reference of Amal Farouk Ali (2009) (6); Walaa Hamdy Farghaly (2011) (15); Ahmed Mahmoud Ibrahim (2011) (4); Rania GaberTawfiq Ahmed (2012) (7); 
Saleh Abdelqer Atrees (2010) (9); Heba Mohamed Ali (2010) (9); Heba Mohamed Ali (2012 ) (14); and Reda Youssef Youssry (2008) (8).

\section{Therefore, the second hypothesis of the study is met.}

According to the data of table (7) , (8) and figures (13), (14) and (15), there are differences in the percentage of positive improvement of the values of special motor capacities, skill styles, training packages, time and standard of performance of motor package "Kata" under study in the sample of the study for the favor of the one that uses against the one that doesn't use the biorhythm curves during the direction of training los under study. The highest difference of improvement percentages $(40.39 \%)$ occurred in the variable of special agility by the skill style the right one-finger spear-hand (Ippon. Nukite). The lowest difference of the percentages of improvement (4.00\%) in the variable of agility of the skill style of straight long right punch (Oi. Zuki) for the favors of special motor skills under study.

The highest difference in the percentage of improvement was $(9.72 \%)$ in the variable of skill performance style of right one-finger spear-hand (Ippon. Nukite), while the lowest difference in the percentages of improvement was $(0.90 \%)$ in the variable of skill style performance standard (Oi. Zuki) for the values of performance standards of the styles under study. This may be attributed to the common use of skill performance of right one-finger spearhand (Ippon. Nukite) in the motor package "Kata" under study.

The higher difference in the percentage of improvement was $(9.72 \%)$ in the variable fo performance standard of the first training package, while the lowest difference in the percentage of improvement was $(4.46 \%)$ in the variable of performance standard of the fourth training package, for the values of training package performance standard of the motor package "Kata" under study.

Difference in the percentages of improvement was (2.50\%) and (11.22\%) in the variable of time and standard of performance of motor package "Kata" under study respectively.

This superiority in the percentages of improvement may be attributed to the use of formation of training loads in the training program in accordance with the biorhythm curves and rating individually directed to the player. The researcher believes superiority in the values of percentages of improvement may be attributed to the effect of the proposed training program structure that was done throughout the similar and identical exercises of skill performance in terms of muscular work, speed performance and track of force me, and direction and application of individually rated training los in accordance with biorhythm curves, in dition to the use of training approach applied, and the properties of the method of training that was applied through the training unit, in dition to the contents of competition exercises for the most common and most used styles that comprise the structure of motor package (Kata) under study through 
training stations. Characteristics of loads dynamics were enforced and employed in the training stations to increase the performance effectiveness in terms of identification of speed and force in accordance with the direction of muscular work, in dition to the use of exercises of training packages through which the speed and force of performance are maintained. This was represented in maintenance of internationally recognized motor rhythm similar to the competition performance, in dition to the match training that contained competition exercises in the form of performance rating skill duties in the form of individual or combined qualifications while maintaining the competitive performance requirements in the official championships to serve the proposed program. This crystallizes the range of using biorhythm curves to direct training loads on the special motor capacities and the performance standard of the skill styles and training packages and motor package "Kata" under study.

This is in agreement with the notes of Amal Farouk Ali (2009) (6); Walaa Hamdy Farghaly (2011) (15); Ahmed Mahmoud Ibrahim (2011) (4); Rania Gaber Tawfiq Ahmed (2012) (7); Saleh Abdelqer Atrees (2010) (9); Heba Mohamed Ali (2012 ) (14); and Reda Youssef Youssry (2008) (8)

Therefore, the third hypothesis of the study is met.

\section{Conclusions and recommendations:}

\section{Conclusions:}

1- Improvement of special motor skills of "Kata" under study in the player of the study. The lowest percentage of improvement between the post measurement and pre measurement in the speed force test of right straight reverse punch (Gayku. Zuki) and was $(8.33 \%)$, while the highest percentage of improvement between the pre and post measurements in the test of front right kick (Mae. Geri) was $(50.00 \%)$ without biorhythm curves were used.

2- Improvement of motor skill of "kata" under study in the player of the study. The lowest percentage of improvement between the pre and post measurements was the lowest in the speed force test of the straight reverse right punch (Gayku. Zuki), and was (15.38\%), while the highest percentage of improvement between the pre and post measurements was in the front right kick test (Mae. Geri) and was $(60.00 \%)$ using biorhythm curves.

3- Performance of individual skill styles of "Kata" under study improved in the player of the study. The lowest percentage of improvement between the pre and post measurements of the skill style of right one-finger spear-hand (Ippon. Nukite) and was (3.39\%), while the highest percentage of improvement was between the pre and post measurements of the performance of skill style of straight reverse right punch (Gayku. Zuki) and the skill style of finger one-finger spear-hand (Ippon. Nukite) and was (8.77\%) without using biorhythm curves.

4- Performance standard of individual skill styles of "Kata" under study improved in the player of the study. The lowest percentage of improvement between the pre and post measurements of performance standard of skill style of straight long right punch (Oi. 
Zuki) and was $(9.52 \%)$. The highest percentage of improvement between the pre and post measurements of performance standard of skill style of front right punch (Mae. Geri) improved and was (14.75\%) using the biorhythm curves.

5- Performance standard of training packages of motor skills "Kata" under study improved in the player of the study. The lowest percentage of improvement between the pre and post measurements of the performance standard of first training package (3.39\%), while the highest percentage of improvement between the pre and post measurements of the second training package performance standard was (8.62\%) without using biorhythm curves.

6- Performance standard of training sections of motor package (Kata) under study improved in the player of the study. The lowest percentage of improvement between the pre and post measurements of the second training section performance standard improved and was (7.94\%). The highest percentage of improvement between the pre and post measurements of the third training section performance standard improved and was (14.75\%) using biorhythm curves.

7- Time and standard of performance of "Kata" under study improved in the player of the study. The percentage of improvement between the pre and post measurements was $(1.67 \%)$ and $(5.17 \%)$ respectively, without use of biorhythm curves.

8- Time and performance standard of motor package "Kata" under study improved in the player of the study. The percentage of improvement between the pre and post measurements was (4.17\%) and (16.39\%), respectively, using biorhythm curves.

\section{Recommendations}

1- To reference the content of structure that forms the proposed training program by using the biorhythm curves to direct special training los to develop the special motor capacities and skill performance of motor package "Kata" in karate.

2- To pay attention to the research plans directed to development of the training status of players of motor package "Kata" to complement the scientific structure of karate.

\section{$\underline{\text { Arabic References: }}$}

1- Ahmed Mahmoud Mohamed

Ibrahim

2- Ahmed Mahmoud Mohamed

Ibrahim

Atef Mohamed Abaza

3- $\quad$ Ahmed Mahmoud Mohamed Ibrahim
:Encyclopedia of theoretical limitations of sports training and application for planning of training programs of karate, Maaref Establishment, Alexandria, 2005 .

:Scientific and Applied Bases for planning the training programs of "Kata" In Karate,Maaref Establishment, Alexandria, 2005 .

:Encyclopedia of training limitations (Theory and Practice) for planning of training programs of karate, Maaref Establishment, Alexandria, 2005 . 
4- Ahmed Mahmoud Mohamed Ibrahim

5- Ahmed Mahmoud Mohamed Ibrahim

Amrallah Ahmed Al-Bossaty

6- Amal Farouk Ali

7- Rania GaberTawfiq Ahmed

8- $\quad$ Reda Youssef

YoussryAbdelqer

9- $\quad$ Saleh Abdelqer Atrees Ali

10- Essam El Din Abdelkhaleq

11- Ali Fahmy Al Bek

12- Ali Fahmy Al Bek and Mohamed Sabry Omar

13- Ali Mohamed Galal El Din
:Scientific and applied encyclopedia of the modern approaches and limitations of training and planning of training programs in Karate,Maaref Establishment, Alexandria, 2011 .

:Effect of Direction of Training Los in accordance with the pattern of biorhythm on some functional significance and skill performance standard of motor packages of karate players, volume of theories and applications, Faculty of Physical Education for Men, Volume II, Alexandria University, 1999.

: Effect of Vartalk Exercises on some functional, physical and skill variables in the junior karate players, Published Research, $3^{\text {rd }}$ International Scientific Conference towards better investment of Egyptian and Arab Sports, Faculty of Physical Education for Men, Zagazig University, 2009.

:Effectiveness of using parallel training for development of special physical capacities and performance standard of BasyDai. Kata Motor Package as players of karate, unpublished master thesis, Alexandria University, 2012.

:Proposed training style for development of motor package (Kata) performance in accordance with the energy production systems in karate, unpublished $\mathrm{PhD}$ thesis, Faculty of Physical Education in Sat, Menoufiya University, 2008 .

:Effect of similar program to performance for development of some special physical capacities on the level of motor performance of motor package Jyun-Kata in the first league players in Karate in Assiut, unpublished $\mathrm{PhD}$ Thesis, Faculty of Physical Education, Assiut University, 2010 .

:Sports Training: Theory and practice, $11^{\text {th }}$ edition, Alexandria, University Book House, 2003.

:Biorhythm and sports achievement, published research, Scientific Conference, symposium on the role of physical education in resolution of modern problems, Faculty of Physical Education for Men, Zagazig University, 1990 .

:Biorhythm and sports achievement, Maaref Establishment, Alexandria, 1994 .

Sports Health: Faculty of Physical Education for Men, 
14- Heba Mohamed Ali Hassan

16- Youssef Dahab Ali rahman
ZagazigUniveristy, 1990 .

: Effect of parallel training on the development of special motor capacities on the level of using some timings of attack approach and effectiveness of attack behavior in karate player, unpublished master thesis, Faculty of Physical Education for Men, Alexandria University, 2012 .

15- WalaaHamdyFarghalyAbdel :Effect of the use of combined parallel training on the development of special physical capacities on the level of motor performance of motor package (Hyan- Ju- Dan) in

Karate,Helwan University, unpublished master thesis, 2011 .

:Physiological reserve and selection and rating of functional efficiency, International Scientific Conference on the strategies of selection and sports talents in light of technology development and information revolution in the period between 30 October and 1 November, Faculty of Physical Education for Men, Alexandria University, 2002 /

\section{Foreign references:}

17- Cutolo M.

18- Froy O. Miskin R.

: Chronobiology and the treatment of rheumatoid arthritis. CurrOpin Rheumatol.2012;24:312-318. : Effect of feeding regimens on circian rhythms: implications for aging and longevity. Aging (Albany NY) 2010;2:7-27.

19- Gokul S. Patil VS. Jailkhani :Oxidant-antioxidant status in blood and tumor tissue of oral R. Hallikeri K. Kattappagari squamous cell carcinoma patients. Oral Dis. 2010;16:29-33. KK.

20- Gupta A. Bhatt ML. Misra MK.

: Lipid peroxidation and antioxidant status in he and neck squamous cell carcinoma patients. Oxid Med Cell Longev. 2009;2:68-72.

21- Masatoshi Nakayama : Best Karate, Vol (11), Kodansha International L T D., Tokyo, Japan, 1990.

22- Taiji, $\mathbf{K}$.
: Karate - Do" Shotokan Ryu", Sedirep Co., Paris, 1982. 
"Effect of Direction of Training Los in accordance with the limitations of biorhythm on

the level of special motor skills and skill performance of motor package (kata) in the

\section{players of the Egyptian National Karate Team"}

The purpose of this study is to identify the effect of using the monthly biorhythm limitations to direct training los of motor capacities on the level of performance of Kata package of Egyptian national team karate players in the sample of the study. The experimental methodology was used with the pre and post measurement of the experimental group on sample of one player in the Egyptian national karate team. The program contained 40 training modules with average of five exercises per week for time that ranges between (2138 seconds) and (3550 seconds), and suitable statistic means was used. The results of this means showed achievement of the goals and hypotheses of the study. The results indicated the following :

1- Positive improvement of percentage of values of special motor capacities- skill styles, training sections- time and level of (Goju. Shi. Ho. Dai. Kata) motor package performance under study in the Egyptian national team player who doesn't use the biorhythm curves during the direction of training los under study.

2- Positive improvement of the percentage of values of the special motor capacities, skill styles, training sections, time and standard of "kata" motor package under study in the sample of the study that uses biorhythm curves during the direction of training los under study.

3- There are differences in the percentages of positive improvement of the values of special motor capacities- skill styles- training sections- time and standard of performance of "Kata" under study in the sample of the study for the favor of the sample that uses biorhythm curves than the one that doesn't use them during the direction of training los under study. 